EQL MEMORANDUM NO, 14

ENVIRONMENTAI QUALITY LABORATORY

CALIFORNIA INSTITUTE OF TECHNOLOGY

\author{
BRINE CHEMISTRY - SCALING AND CORROSION \\ GEOTHERMAL RESEARCH STUDY IN THE \\ SALTON SEA REGION OF CALIFORNIA
}

by

Michael R. Hoffmann

July 1975

Supported by Energy Research and Development Administration grant ERDA-SAN No. AT (04-3)-1086; formerly NSF AER 75-01748 
The potential for producing electrical power from the energy stored in the unusually hot, hypersaline brine deposits of the Salton Sea KGRA (Known Geothermal Resouxce Area) is large. Unfortunately, utilization of geothermal energy is currently hindered by severe scaling and corrosion problems. In order to solve these problems and to facilitate the commercial exploitation of geothermal resources in the Salton Sea KGRA, a research program that will determine the dependency of scaling and corrosion on brine composition and process conditions is necessary. The purpose of this report is to recommend a reasonable program of brine chemistry research that will result in the development of methods for predicting and controlling scale deposition, and in guidelines for the selection of corrosion-resistant construction materials.

This report is structured in the following manner: First, background information, which is necessary for the understanding of the problems of scaling and corrosion in the Salton Sea KGRA, is presented through a review of the history of geothermal exploration and development in the Salton Sea. Second, 1iterature relevant to the geochemistry of the Salton sea field is reviewed and important results are exphasized. Third, current research efforts directed toward actual power plant construction are summarized and evaluated. Fourth, research which has been proposed but is not currently funded is discussed. Fifth, because silica scaling has been the most troublesome problem in the past, the basic chemistry of silica and its relationship to scaling is discussed. Sixth, recommendations for future research are made in which a fundamental engineering approach is emphasized. In this approach, experinents would be conducted on actual process equipment and detailed chenical analyses would be performed on site in we11-equipped field laboratories. 
FOREWORD

I

Introduction

This document is one of several that report the results of a study carried out by the EQL during 1975. This investigation was directed at definition of and support for a geothermal resource demonstration program to be conducted at the Salton Sea KGRA. 'The originating agency was NSF/RANN, but in January of 1975 the responsibility for the project was transferred to ERDA. It was anticipated that the results of the research would be continuously fed in to the demonstration program, which was originally anticipated to be initiated during the period of this present grant. However, the demonstration progran was not initiated during that time. Those programs are now getting underway, and it is hoped that these results may be useful to ERDA and the contractors in arriving at a program of research. A summary of results in each of the several research areas is given in the following paragraphs, in order that the reader can place the present report in context.

\section{Engineering Studies}

For high-temperature reservoirs the technique of pumping wells was found to be inferior to flashing flow (self-flow); as theory suggests a considerable advantage to be gained by increasing well diameter in the upper (flashing) parts of the well bore. A more thorough analytical treatment, with experimental verification, is recommended. This technique may offer a major savings in field developnent cost.

For high-temperature reservoirs it was found that multiple-flash direct steam systems offer superiox performance as compared to binary processes. Total-flow expanders offer promise, however, and their development is recommended. Even for low-temperature reservoirs, binary processes offex no significant theoretical performance advantage as compaxed to flash processes. It was not possible to carry out cost comparisons during the study. 
This work is reported in EQL Report No. 10, "Comparison of Brine Production Methods and Conversion Processes for Geothermal Electric Power Generation."

\section{Environmental Geochemistry}

The review of trace element analyses of Salton Sea KGRA brines indicates that more sophisticated sampling and analytic techiques will have to be applied to be sure that minor constituent content is properly understood. Generally, environmental problems will come from volatile species. A program of analysis is suggested that would indicate what chemical compounds may present environmental hazards. This information is necessary before control requirements could be formulated. The work is reported in an open file EQL document, "Trace Elenent Problems," available at EQL.

IV Water Chemistry

It was found that much of the existing useful empirical engineering information concerning scale and corrosion is not available in the open literature. Unless this inforthation is released by its owners, a future research program may have to duplicate past experience. Several proposed lines of research on the problem were investigated. Some of the most: basic approaches, beginning with fundanental chemistry, were judged to be too lengthy or difficult to yield practical results. A basic chemical engineering approach was identified and recomnended. The work is reported in EQL Memorandur No. 14, "Brine Chemistry - Scaling and Corrosion."

V Geology

A geology investigation was to have been provided by faculty consultants from University of California at Riverside, but this investigation has proven to be unecessary. The current geologic knowledge of the Salton Sea KGRA was recently published in the Ph.D. dissertation of Randall. The UCR group had already formulated a continuing program of geological research at the Salton Sea, and proposed the work to NSF. The proposal has been funded. Therefore, no additional research prograns are recomnended at this time. 
The selected consultants (Petroleum Engineering group at Stanford University) report that methods appropriate to evaluation of the Salton Sea reservoir are contained in the paper "Pressure Transient Analysis for Geothermal Wells" by Henry J. Ramey, delivered at the Second UN Geothermal Symposium in San Francisco. The exact program of measurements can be formulated only when actual well flow programs are determined. No additional research peculiar to the Salton Sea KGRA was recommended. The pressure transient analysis was strongly recommended for implementation during the demonstration program.

\section{Econonics}

Because the Salton Sea KGRA is largely leased, and because business arrangements have been made between producers, utilities and leaseholders, our general study of geothermal economics can help one to understand some aspects of the economics of the Salton Sea field, but cannot be expected to further the demonstration program. The study was carried out and is published in EQL Report No. I1, "The Economics of the Geothermal Energy Industry, Based on Data Through 1974."

\section{Legal and Institutional}

A number of legal and institutional issues are often mentioned as hindrances to geothemal development. This study found that the problems are poorly documented in the literature, and it is not possible on the basis of the published record to recommend specific changes in the law or institutions pertaining to geothermal development. Therefore, a program of research to identify and properly document the issues is recomended. It was also found that the difficulties facing the geothemal industry in general are not met at the Salton Sea KGRA, because so many of the problems have already been overcome there. Therefore it is concluded that a demonstration program at the Salton Sea will do little to illuminate or solve most legal and institutional issues being met elsewhere. The work is reported in an open file EQL document, "Legal and Institutional Factors."

*Progress in this regard has been made by the recent publication of a Draft Report on Geothermal Energy and the Law by the University of Sonthern California Law Center. 
Preface ........ . . . . . . . . . . . . . . . 1

II Introduction . . . . . . . . . . . . . . . . . . . 4 History . . . . . . . . . . . . . . . . . . 4 Scaling ........................... . . 9 Corrosion ............................. . 12 Research and Development .................... . . 13

II Literature Review . . . . . . . . . . . . . . . . 15 Brine Analyses . . . . . . . . . . . . . . . . . 20

IV Current Research Programs ... . . . . . . . . . . . . 21

V Proposed Research Programs . . . . . . . . . . . . . . . 25

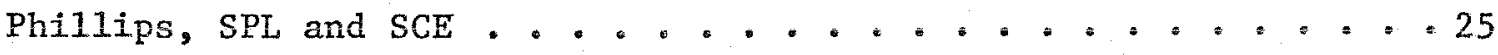

San Diego Gas and Electric - Ben Holt Co. . . . . . . . . . . 26 Lawrence Livermore Laboratory (LLL) . . . . . . . . . . . . 27 Occidental Research Corporation... . . . . . . . . . . 28 A Recommended Research Program in Geothermal Chemistry . . . . . 30 VI Silica Chemistry Review . . . . . . . . . . . . . . 32 Chemistry Background .............................. 32 General Silica References .................... 35 Current Research on Silica in Geothermal Systems . . . . . . . 35 Silica Scale Control - In Practice . . . . . . . . . . . . 36

VII Recommended Research Program . . . . . . . . . . . . . . . 38 References.............................42 4

Figure 1 - Geothermal Well Locations for the Salton Sea GRA . . . . . 8

Table 1 - Wells of the Salton Sea Geothermal Field . . . . . . . . . 7

Table 2 - Chemical Composition of Geothermal Brines from Salton Sea KGRA Wells ......... . . . ....... . . . . 17 
The principal objective of this report is to recomend a program of brine chemistry research which would facilitate the cominercial exploitation of geothermal resources in the Salton Sea Anomaly. Clearly, the complex brine chemistry and the associated problems of scaling and corrosion are the most significant deterrents to commercial exploitation.

The data and information which were necessary to recommend an appropriate research program were obtained from a variety of sources. Initially, a comprehensive manual 1iterature search of Chemical Abstracts, Bibliography and Index of Geology of the Geological Society of America, and the Bibliography of North Anerican Geology was undertaken. To supplement this search, a computexized search was performed on CHEMCON by SDC International Search Sexvice using 20 key-words under the title, "Geothermal Energy Systems".

Because of the fact that most of the early enginearing and sclentiric work on geothermal systems in the Salton sea area has been performed by private industry, much of the data and information is not available to the general scientific commity. In order to learn more about this private data bank and accumulated engineering knowledge, individuals who have worked closely on vaxious geothermal projects in the Salton Sea area were consulted. The list of geothermal experts who were consulted is as follows: Dr. Robert C. Axtmann, Professor of Chemical Engineering, Princeton University; Dr. H. I. Barnes, Professor of Geoscience; Pennsylvania State University; John Carter, U.S. Bureau of Mines, College Park, Maryland; Dr. Wilfred A. Elders, Professor of Earth Sciences, University of California, Riverside; Dr. Robert O. Fournier, U.S. Geological Survey, Menlo Paxk, California; Dr. Fred Fulton, Lawrence Livermore Laboratories, Livermore, California; Dr. Harold C. Helgeson, Professor of Geology, University of California, Berkeley; Dr. Donald Jackson, Lawrence Livermore Laboracories, Livermore; Glenn Marsh, Union OIl Co., Brea, California; Fred MacDougall, Shell 0il Co., former Project Manager for "Project Hades - Salton Sea 
Geotherma1 Development", present1y Manager of Business Affairs, She11 Development Company, Houston, Texas; Dr. Lawrence B. Owen, Lawrence Livermore Laboratories; Dr. Edward F. Wahl, Occidental Research Corporaation, La Verne, California;* Richard Wyman, former geothermal project geologist for Shell Development Company, Shell-Canadian, Calgary, Canada. From these scientists and engineers additional information, reference sources, and personal opinions were obtained. There was a remarkable concurrence of opinion about the current status of research, about basic information available, and about the directions for future research that would result in the quickest solution to technical difficulties due to scaling and corrosion. As had been expected from the initial literature search, there is a paucity of reliable engineering and geochemical data which has been collected from wells drilled in the hypersaline anomaly.

Regrettably, much of the fundamental data which has been collected, and engineering solutions to various problems which were encountered, are being currently withheld from public inspection because of the potential commercial and competitive value of such information. For example, $\mathrm{H}$. W. Diamond $^{1}$ of Morton International, Inc. and Imperial Thermal Products, Inc., stated in a 1970 testimony before the Geothermal Resources Board of California:
"We have identified and either solved or learned to live with the major technical problems in the operation of geothermal wells to purify steam for power generation and to recover minerals.... Specific references have been made by others to the unsolved problems of corrosion, scaling, and bittern disposal as deterrents to the development of leases.... Our pilot plant operation shows that all of the problems are amenable to economic solution.... We have concluded that geothermal resources in this area are ready for comercial development provided we can obtain a satisfactory market for power and minerals."

Attempts by various investigators to gain access to the Morton data file have been fruitless; but, as a result of recent negotiations with Shell oil Company, it is hoped that their data files will be opened for general inspection. Fred MacDouga11, ${ }^{2}$ former project manager for She11's

*Formerly Garrett Research and Development 
geothermal research efforts in the Salton Sea anomaly, has stated, "We collected a wealth of engineering and geochemical data which would be invaluable to anyone initiating a research program in the hypersaline area."

Additional information was obtained from attending the "Workshop on Materials Problem Associated with the Development of Geothermal Energy Systems", which was sponsored by the Bureau of Mines and held in Holtvi11e, California, 16-18 May 1975. At this meeting the status of current research and development projects in the Imperial Valley was discussed and preliminary research results were presented. The highlight of this meeting was a field trip to some of the more important well sites in the Imperial Valley. The following geothermal sites in the hypersaline area were visited: Philips Petroleum Company - Sinclair Well 非, San Diego Gas and Eiectric Company - Magma Power Company Wells, Morton International, Inc. - Imperial Irrigation District Well $\# 1$, and Union Oil Company - River Ranch We11 \#1. Lower salinity and lower temperature wells were visited on the Heber and East Mesa sites. Another opportunity to visit well sites and to see the wells under actual operating conditions was provided by the Geothemal Energy group of Lawrence Livernore Laboratories and the SCE consortium operators. On this trip of 14-16 Apri1 1975, well sites at East Mesa, Sinclair $k_{4}$ and Cerro Prieto were visited. Sufficient time was allowed for extensive questioning of operating personnel and for personal observation. The final meeting attended before writing this report was the Second United Nations Symposium on the Development and Use of Geothermal Resources held in San Francisco, California, 20-29 May 1975.

This report will consist of six additional sections. The topics which will be discussed will be first, an historical introduction to the problems of scaling and corrosion in high temperature-hypersaline brines; second, a review of available Salton Sea-related literature; third, a discussion of current research efforts in scale and corrosion control; fourth, future research proposed for the Salton Sea anomaly; fifth a review of basic silica chemistry; and finally, recommendations for future research emphasizing an engineering approach. 


\section{History}

The history of geothermal exploration and development in the Salton Sea area began in 1927 when three wells were drilled by the Pioneer Development Company ${ }^{3}$ in search of a natural source of steam suitable for power generation. Their search was successful when steam and hot water were produced from the wells, but, unfortunately, the temperature, pressure, and volume were not suitable for commercial exploitation. With the production of steam infeasible, the underground search shifted to $\mathrm{CO}_{2}$ for dry ice production. The first well drilling was discontinued because high temperature waters were encountered at a depth of 1,054 feet. More than 50 shallow wells were eventually drilled to provide $\mathrm{CO}_{2}$ for a dry ice plant. White 4 foretold the problem of scaling when he reported that during a 1948 visit to an old well on Mullet Island in the Salton Sea a metallic film was deposited on a steel tape used to make well measurements.

The first well to produce substantial quantities of stean and hot water was the Sinclair 非 we11, which was originally drilled as a wildcat oil well by the Kent Imperial Oil Company in 1957. When hot water and steam instead of oil were produced, the well was prepared for steam production. In $1959^{5}$ a small power generating plant was installed, but after four months of intermittent operation the well was plugged by scale formation at the surface. In subsequent years, a number of additional wells were drilled in the Salton Sea region. The Imperial Irrigation District granted a long-term lease to $0^{\prime} \mathrm{Ne} 111$ Geothermal, Inc. for the development of steam resources. The first $0^{\prime}$ Neill well was Sportsman \#1, which was drilled to a depth of 4,729 feet. During a three-day test period, 56,000 $\mathrm{Ibs} / \mathrm{hr}$ of steam and $258,000 \mathrm{lbs} / \mathrm{hr}$ of hypersaline brine (334,000 ppm by welght of dissolved solids) ${ }^{6}$ were produced. A second $0^{\prime} \mathrm{Ne} I 1$ well, I.I.D. \#1, was drilled in 1962 to a depth of 5,232 feet with flow conditions at the wellhead of 125,000 1bs/hr of steam, 500,000 lbs/hr of brine, 200 psig and $207^{\circ} \mathrm{C}$. During a threemonth production test, enormous quantities of 
a dark material precipitated in a 275-foot long discharge pipe. It was estimated that five to eight tons of scale were precipitated during the three months. ${ }^{7}$ A semi-quantitative spectrographic analysis of the scale indicated that the major constituent was silicon with relatively high concentrations of iron, silver and copper. A fire assay of the deposit indicated a silver content of 381 ounces per ton (1.2\%).

In subsequent years, additional wells were drilled in the immediate vicinity of the $0^{\prime N e i l l ~ w e 11 s . ~ E i g h t ~ o f ~ t h e s e ~ w e l l s ~ p r o d u c e d ~ s t e a n ~ a n d ~}$ hot hypersaline water in two-phase flow at the wellhead. Analyses of the brines indicate a percentage of dissolved solids in the range of 20 to 25 percent by weight. Consequently, severe corrosion and scaling in the wells and supporting equipment was encountered. In 1965, Impexial Thermal products, a subsidiary of Morton International, Inc, used the I.I.D. well fil to Investigate the technical problems associated with commercial use of geothermal brines for power generation and mineral extraction. A 3 MW steam power plant was constructed and evaporation ponds were located nearby for residual brine disposal. Power was actually generated for a short period, but a high level of carryover of salts in the stean phase caused severe scaling and corrosion of the turbine blades and auxiliary equipment. Eventually power generation was discontinued because of the scaling problem.

In 1964-65, the Earth Energy Company, a subsidiary of Union-Pure oil Company, 8 operated a pilot plant project on River Ranch well $\$ 1$ to recover potassium chloride from the geothermal brine. Their attempt to extract "potash" was hampered by a corrosion rate of $20 \mathrm{mils} / \mathrm{yr}$ in areas of direct brine contact and a corxosion rate of $80 \mathrm{mils} / \mathrm{yr}$ in the stean contact axea. Two types of scale wexe observed. The first type of scale was a hard opaline scale which deposited on a retrievable well Iiner at a rate of $1 / 8 \mathrm{inch} / \mathrm{yr}$. The primary constituents of this scale were silica, iron oxide and heavy metal sulfides. Apparently this opaline scale formed a protective coating on the well liner and decreased the rate of corrosion. The second and more serious scaling occurred after the 
brine was flashed at the wellhead. The scale which formed after flashing was a soft putty-like material that was primarily silica with traces of iron oxide. A 4-inch production pipe was choked back to one inch after a few weeks of production. Because of these insurmountable problems, the producing well was shut in during the fall of 1965 .

In 1972, a consortium, consisting of Phillips Petroleum Company, Southern Pacific Land Company, and Southern California Edison, began a research program on the Sinclair wells 非 and $\#^{4}$, which were originally drilled in 1963 and 1964 by Western Geothermal to produce $\mathrm{CaCl}_{2}{ }^{\circ}$. The current research and development program is aimed at the eventual utilization of the brine for power production and mineral recovery. The two wells were reconditioned and an inter-well fluid line was constructed for the reinjection of brine wastes from well \#4 to well \#3. To initiate flow during the original drilling, a 1,220-meter string of 1-1/4 inch tubing had been introduced into the well for nitrogen injection. Recently, attempts were made to recover the string, but only $336 \mathrm{~m}$ of a severely corroded stump were recovered. The top poxtion of the string was coated with a protective sheet of scale, while the bottom suffered extensive pitting. The well casing was covered with a black siliceous scale $1-1 / 4$ inch thick. Analysis of the scale revealed that it consisted mainly of amorphous silica with traces of iron in the form of siderite $\left(\mathrm{FeCO}_{3}\right)$, magnetite $\left(\mathrm{Fe}_{3} \mathrm{O}_{4}\right)$ and pyrite $\left(\mathrm{FeS}_{2}\right)$. During a five-month period of operation, an insignificant amount of scale ( $\left.1 / 32^{\prime \prime}\right)$ deposited in discharge pipes. This was achieved by choking the well back to a minimum point of stability necessary to maintain maximum wellhead temperature and pressure. It should be noted that the maximum downhole temperature recorded for Sinclair 非 is $220^{\circ} \mathrm{C}$, whereas I.I.D. \#1 has a marmum of $328^{\circ} \mathrm{C}$ and River Ranch 1 has a maximum of $345^{\circ} \mathrm{C}$. (See Table 1 and Figure 1 for well data and locations.) This temperature difference is significant because the solubility of silica as quartz has a strong positive temperature dependency; therefore, one would expect to see a higher rate of silica deposition in the operation of I.I.D. \#I and River Ranch $\# 1$.

*This value is undoubtedly too low! 
TABLE 1

Wells of the Salton Sea Geothermal Field

WeII

Pioneer $\# 1$ Pioneer $\#^{2}$

Pioneer 非 3

Sinclair 非

Sportsman $\# 1$

I.I.D. \#I

Sinclair 非

I.I.D. \# 2

I River Ranch 非

State $\#_{1}$

J.J. Elmore \# 1

Sinclair 非4.

Hudson $\mathbb{N}_{1}$

I.I.D. 非 3

Magmamax $\# 1$

Woolsey \#1

Magmamax $\# 2$

Magmamax 非 3

Magmamax \#4:
Operator

(Original Operator)

Pioneer Development Co.

Pioneer Development Co.

Pioneer Development Co.

Geothermal Energy \& Mineral Corp. (Kent Imperial)

Imperial Thermal Products, Inc. (O'Neill Geothermal)

Imperial Thermal Products, Inc. (O'Neil1 Geothermal)

Geothermal Energy \& Mineral Corp. (Western GeothermaI)

Imperial Thermal Products; Inc. (She11 Development)

Magma Power Co. (Earth Energy)

Imperial Thermal Products, Inc. (She11 Development)

Union $\mathrm{Oil} C \mathrm{Co}$, of Calif. (Earth Energy)

Geothermal Energy \& Mineral Corp. (Western Geothermal)

Magma Power Co. (Earth Energy)

Imperial Thermal Products, Inc.

Magma Power Co. (Magma Energy)

Magma Power Co. (Magma Inergy)

Magma Power Co. (Magma Energy)

Magna Power Co. (Magma Energy)

Magma Power Co. (Magma Energy)

\begin{tabular}{|c|c|c|c|c|}
\hline $\begin{array}{l}\text { Date } \\
\text { Drilled }\end{array}$ & $\begin{array}{c}\text { Depth } \\
\text { (meters) }\end{array}$ & $\begin{array}{l}\text { Temp. } \\
\left({ }^{\circ} \mathrm{C}\right)\end{array}$ & $\begin{array}{c}\Delta \mathrm{H} \\
\mathrm{CaI} / \mathrm{g} \\
\end{array}$ & $\begin{array}{l}\rho(\mathrm{g} / \mathrm{cc}) \\
\text { at } 25^{\circ} \mathrm{C}\end{array}$ \\
\hline $\begin{array}{r}6 / 27 \\
10 / 27 \\
2 / 28 \\
2 / 58\end{array}$ & $\begin{array}{r}222 \\
385 \\
449 \\
1,440\end{array}$ & 294 & & \\
\hline $3 / 61$ & 1,442 & 310 & 220 & 1.207 \\
\hline $3 / 62$ & 1,595 & 328 & 228 & 1.239 \\
\hline $4 / 63$ & 2,110 & 280 & 240 & 1.180 \\
\hline $12 / 63$ & 1,769 & 330 & 235 & \\
\hline $1 / 64$ & 2,469 & 345 & 250 & \\
\hline $5 / 64$ & 1,475 & 310 & 280 & \\
\hline $5 / 64$ & 2,170 & 360 & 285 & \\
\hline $6 / 64$ & 1,617 & 220 & 210 & 1.220 \\
\hline $7 / 64$ & 1,864 & 260 & 225 & \\
\hline $\begin{array}{l}3 / 65 \\
1 / 72\end{array}$ & $\begin{array}{l}517 \\
855\end{array}$ & $\begin{array}{l}200 \\
265\end{array}$ & 250 & 1.023 \\
\hline $3 / 72$ & 732 & 238 & & 1.082 \\
\hline $11 / 72$ & 1,312 & 278 & & \\
\hline $10 / 72$ & 1,220 & 321 & & \\
\hline $12 / 72$ & 780 & 240 & & \\
\hline
\end{tabular}




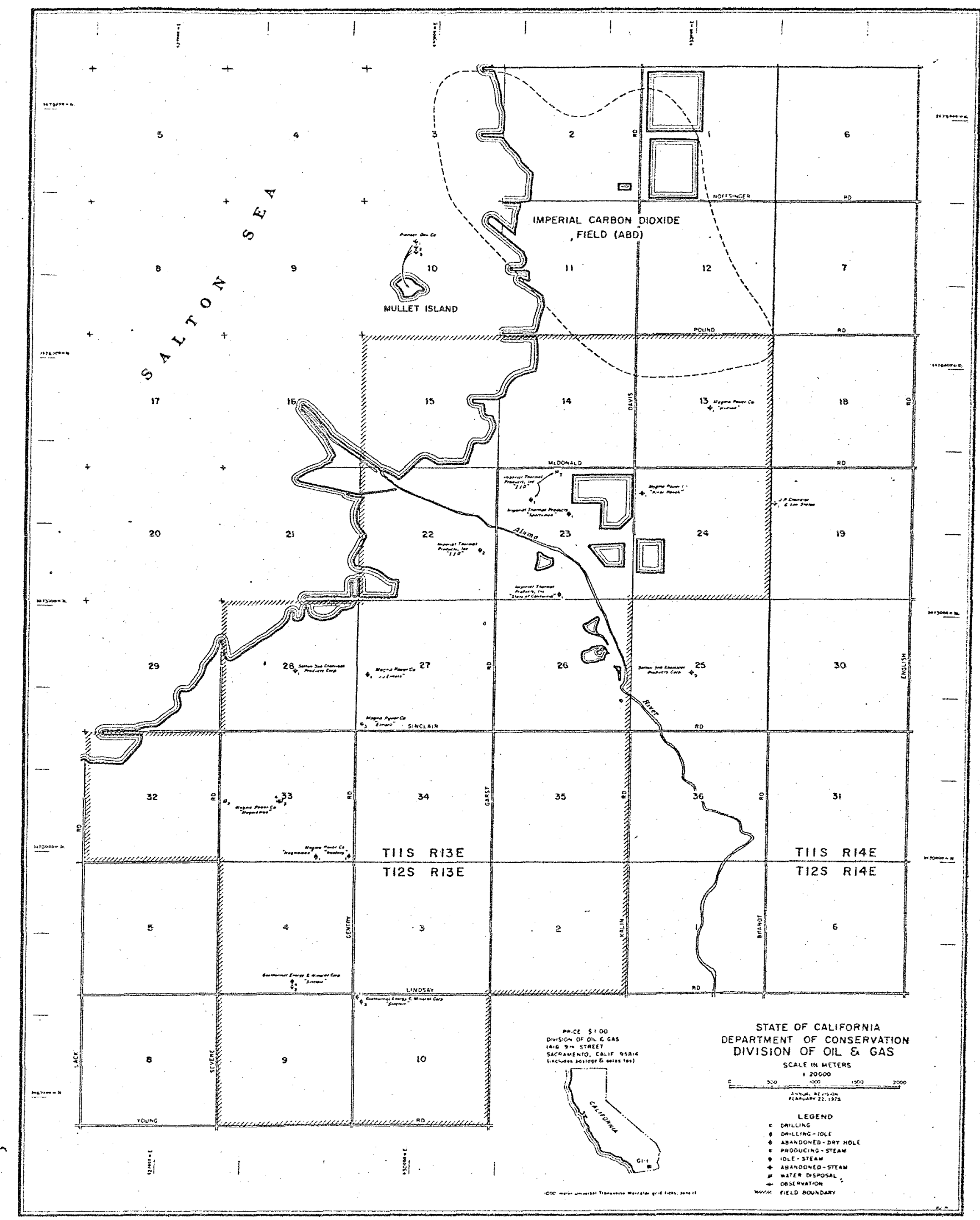

Figure 1: Geothermal Well Locations for the Salton Sea KGRA 
The newest wells in the Salton Sea field are the Magmamax wells, which are being operated jointly by San Diego Gas and Electric and the Magma Power Company. Four wells were drilled in the Niland area during 1972. In 1973, a sma11 test facility was constructed to study a binary cycle system for power generation. 10 After separation of steam from the brine, the steam was run through a heat exchanger, but heat transfer coefficients dropped drastically when hard scale deposits built up on the surface of the exchanger. The scale consisted primarily of silica with high levels of iron and lead. Subsequently a countercurrent flow system similar to a distillation column was used to scrub the steam after initial separation. This effectively eliminated the scaling problem within the heat exchangers, but a soft amorphous scale was encountered in the reinjection line. After one month of operation the dianeter of the line was reduced from $6^{\prime \prime}$ to $I^{\prime \prime}$.

\section{Scaling}

The purpose of the preceding historical section was to illustrate emphatically that the problems of scaling and corrosion have prevented the utilization of geothermal energy from the Salton Sea field. Silica scaling appears to be the more difficult of the two problems to solve technica11y.

Silica-containing geothermal brines are formed by the interaction of water with quartz at temperatures above $200^{\circ} \mathrm{C}^{11}$ and the silica present in the downhole environment is in the monomeric state. In a downole environment where the temperature would be near $350^{\circ} \mathrm{C}$, the equilibrium concentration of silica should be equal to the quartz solubility at that temperature (i.e.s ${ }^{7} 730 \mathrm{ppm}$ ). ${ }^{12}$ When the brine is brought to the surface, the temperature falls with a corresponding decrease in the equilibrium solubility of silica. For example, at a wellhead temperature of $220^{\circ} \mathrm{C}$ the equilibrium solubility of silica drops to $340 \mathrm{ppm}$, and therefore the brine should be supersaturated with respect to dissolved silica. This simple temperature dependent effect is compounded by flashing of the brine into steam. Flashing occurs at a depth in the well at which 
the fluid pressure equals the vapor pressure. When this happens, there is a significant increase in concentration of dissolved solids in the aqueous phase, and as a consequence a certain fraction of the dissolved silica can precipitate out of solution and deposit on the well liner, separators, and discharge lines as either a hard opaline or soft amorphous scale. Silica invariably precipitates from solutions as amorphous silica regardless of the original source of silica. It is well known that the equilibrium solubility of amorphous silica is greater than that of quartz. At $350^{\circ} \mathrm{C}$, the solubility of amorphous silica would be approximately 1,200 ppm. ${ }^{12}$ In supersaturated solutions, hydrated monomeric silica polymerizes with the elimination of $\mathrm{H}_{2} \mathrm{O}$ to form, first, disilicic acid and subsequently higher polymeric forms until colloidal particles are formed. The rate of polymexization is sensitive to temperature, $\mathrm{pH}$, and the degree of initial supersaturation. The rate increases with a rise in temperature and an increase in $\mathrm{pH}$. The colloidal particles will eventually aggregate at. sufficiently high concentrations to form silica gel or precipitate. The precipitation of amorphous silica from a supersaturated solution is a relatively slow process in the absence of catalytic influences. Some geothermal brines may flow from the well as a clear solution, but after standing at ambient temperatures the solution will begin to cloud and eventually a heavy precipitate will form and settle. Such is the case with geothermal brines from Wairakei ${ }^{13}$ and Ahuachapan. ${ }^{14}$

The rates of silica deposition from geothermal brines from the Salton Sea field appear to be strongly influenced by the high heavy netal content of the brines. They have unusually high concentrations of iron, manganese and zinc. 15,16 It is conceivable that these polyvalent cations act as flocculating agents which reduce the charge on polymeric silica and allow particles to come together as more compact aggregates in the form of a precipitate instead of a gel. ${ }^{17}$. The net effect of cations on a silica water system is to increase the rate of precipitation and in some cases reduce the solubility. In addition to cations the rate of precipitation is strongly influenced by $\mathrm{pH}$. A maximum rate is observed between $\mathrm{pH} 5$ and 8 and a minimum between $\mathrm{pH} 1$ and 3.18 
Skinner, et al. ${ }^{16}$ have studied the scale deposits from I.I.D. well \#1 using $X$-ray fluorescence and $X$-ray powder diffraction techniques. The scale is an iron-rich amorphous silica deposit which has high levels of $\mathrm{Cu}(20 \%)$ and $\mathrm{Ag}(6 \%)$ present as bornite $\left\{\mathrm{Cu}_{5} \mathrm{FeS}_{4}\right.$ or $\left.(\mathrm{Cu}, \mathrm{Ag})_{5} \mathrm{FeS}_{4}\right\}$, digenite $\left\{\mathrm{Cu}_{9} \mathrm{~S}_{5}\right.$ or $\left.\left(\mathrm{Cu}_{4} \mathrm{Ag}\right)_{9} \mathrm{~S}_{5}\right\}$, chalcopyrite $\left(\mathrm{CuFeS}_{2}\right)$, chalcocite $\left\{\mathrm{Cu}_{2} \mathrm{~S}\right.$ or $\left.(\mathrm{Cu}, \mathrm{Ag})_{2} \mathrm{~S}\right\}$, and other sulfide minerals. Surprisingly, free elemental silver was also isolated and identified. The $X$-ray powder diffraction patterns did not have any diffraction lines belonging to crystalline silicates, and they also verified that silica is in an amorphous, opaline form.

Fortunately calcite scaling is not a problem in the high-temperature Salton Sea brines, even though the $\left[\mathrm{Ca}^{+2}\right]$ are unusually high (i.e., 28,000 ppm for I.I.D. 非). ${ }^{16}$ In lower temperature and lower salinity brines, calcite scaling occurs when the pressure of the brine is reduced during its ascent of the we11. Because of the lower pressure, dissolved $\mathrm{CO}_{2}$ has a tendency to escape from solution resulting in an increase in pH according to equations $1-4$.

$$
\begin{aligned}
& \mathrm{CO}_{2}(\mathrm{~g})+\mathrm{H}_{2} \mathrm{O} \neq \mathrm{H}_{2} \mathrm{CO}_{3} * \\
& \mathrm{H}_{2} \mathrm{CO}_{3} *=\mathrm{CO}_{2}(\mathrm{aq})+\mathrm{H}_{2} \mathrm{CO}_{3} \text { (definition) } \\
& \mathrm{H}_{2} \mathrm{CO}_{3} * \mathrm{H}^{+}+\mathrm{HCO}_{3}^{-} \\
& \mathrm{HCO}_{3}^{-} \neq \mathrm{CO}_{3}=+\mathrm{H}^{+}
\end{aligned}
$$

As $\mathrm{CO}_{2}(\mathrm{~g})$ escapes from solution the equilibrium relationships described in equations $1-4$ shift to the left resulting in an increase in $\mathrm{pH}$ and precipitation of calcite (calcium carbonate) according to equation 5.

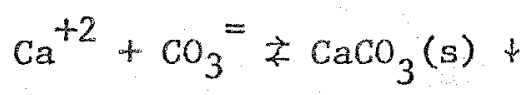

Calcite solubility has an inverse temperature dependence: As temperature increases the solubility of calcite decreases; therefore, at downhole temperatures of approximately $325^{\circ} \mathrm{C}$, the solubility of calcite will be small. As the temperature of the brine drops during its ascent to the surface, the solubility of calcite will actually increase and any calcite which forms due to a loss of $\mathrm{CO}_{2}$ may possibly not precipitate. 


\section{Corrosion}

Corrosion of construction materials used on geothermal well sites and power generating plants is another vexing problem; but fortunately the effects of corrosion can be minimized by proper selection of corrosionresistant alloys or materials.

The combination of high-temperature and high-chloride ion concentrations $(150,000 \mathrm{ppm}$ or $4.2 \mathrm{M})$ of the Salton Sea geothermal brines cause severe corrosion of carbon steel well casing. An unprotected casing will dissolve and expose the surrounding cement. Downhole corrosion rates are a function of temperature, brine chemistry, flow rate, and depth within the well. With hypersaline brines severe corrosion begins in the range of 300 to 600 meters. ${ }^{19}$ Above 300 meters opaline scaling deposits will provide a protective coating. other factors which affect corrosion rates are $\mathrm{pH}$ and dissolved gas such as $\mathrm{O}_{2}, \mathrm{CO}_{2}, \mathrm{H}_{2} \mathrm{~S}$, and $\mathrm{NH}_{3}$. Aquated $\mathrm{CO}_{2}$ and $\mathrm{H}_{2} \mathrm{~S}$ are acidic gases which will lower the $\mathrm{pH}$ into the acid region. In addition to the $\mathrm{pH}$ modification, $\mathrm{H}_{2} \mathrm{~S}$ gas will also accelerate blistering and embrittlement of steels. Dissolved oxygen accelerates corrosion by a process known as cathodic depolarization. 20 "Corrosion is the destructive attack of a metal by chemical or electrochemical reaction with its environment." 20 The types of corrosion damage to metals used in geothermal environments are: 1) uniform attack - ordinary rusting; 2) pitting - a situation in which corrosive attack occurs in a limited area which results in the formation of a deep or shallow pit; 3) stress corrosion cracking when a metal is subject to a constant tensile stress in a corrosive environment, it cracks. Generally high salinity accelerates electrochemical corrosion by increasing the conductivity of the solvent medium, and high chloride ion concentrations will increase the susceptibility of austenitic stainless steel to pitting and stress corrosion cracking. 21

Ferrous iron presents an additional corrosion problem in Salton Sea geothermal brines. $\mathrm{Fe}^{+2}$ is readily oxidized by $\mathrm{O}_{2}$ to $\mathrm{Fe}^{+3}$, and $\mathrm{Fe}^{+3}$ wiIl then hydrolyze in solution to form ferric hydroxide with the concomitant release of protons which will lower the $\mathrm{pH}$ of the brine according to 
equations 6 and 7.

$$
\begin{aligned}
& 2 \mathrm{Fe}^{+2}+1 / 2 \mathrm{O}_{2}+2 \mathrm{H}^{+}=2 \mathrm{Fe}^{+3}+\mathrm{H}_{2} \mathrm{O} \\
& 2 \mathrm{Fe}^{+3}+6 \mathrm{H}_{2} \mathrm{O}=2 \mathrm{Fe}(\mathrm{OH})_{3}+6 \mathrm{H}^{+}
\end{aligned}
$$

Helgeson ${ }^{22}$ reports that the $\mathrm{pH}$ of ponded brines from the Shell Development Company wells dropped to between 1 and 2 . He also reported that the acid brines were more corrosive to implements and damaging to clothes than concentrated acid.

Corrosion damage in geothermal systems can be minimized by properly selecting corrosion resistant alloys or materials that would be most appropriate for a particular phase of operation, such as, in wells, in surface lines, in separators, in turbines, in exchangers, in cooling towers, and in discharge lines. Oxygen must be carefully excluded from a system in order to minimize corrosion rates. In well casings formation of a hard, glassy silica scale may be the best corrosion preventative, although an incomplete coating could intensify crevice corrosion, according to data from Atomic Intemational. 87

\section{Research and Development}

"A11 the problems are interconnected," are the words Professor Harold Helgeson ${ }^{22}$ used to describe the Salton Sea geothermal field when he was asked to give his opinion on the status of research and development in the area. The technical problems alone are overwhelming, but quick solutions to these problems are presently hindexed by non-technical matters which include proprietary rights, leasing arrangements, and legal and institutional problems and operating cost. For example, the geothermal energy development program of Lawrence Livermore Laboratory is currently paying a service fee of $\$ 35,000 /$ operating month ${ }^{33}$ for use of the brines flowing from Sinclair $\#_{4}$. Thus substantial costs must be devoted to gaining access to natural geothermal brines before basic experimentation can begin. Another problem is the lack of data and information exchange among the various groups that have worked in the area from the beginning of the modern era in 1957. Much of the current research effort may 
simply be a duplication of research already completed but not disseminated. Knowledge of some of the basic engineering data obtained for the various wells that have been drilled would be a valuable aid in the design of an appropriate applied chemistry program. Before the quickest possible solution to the problens of scaling and corrosion can be achieved, the performance characteristics of wells should be documented under actual operating conditions. Scaling and corrosion may be important in one phase of the operation and not important in another. There are many hypothetical methods to control scaling, either by treating the bulk brine or by protecting specific surfaces; but, before a particular method can be tested and to avoid unnecessary work, knowledge of the exact location and extent of scaling within the system is necessary.

Improved analytical techniques for the sampling and analysis of brines are necessary. Present analytical procedures are not standardized; therefore, published data on the composition of various Salton Sea brines may not be reliable. Also significant advances in analytical procedures for trace metal determination have been made within the last few years. To complicate matters, it is probable that the brine compositions of various wells within the Salton Sea field will vary significantly, and these compositional variations may result in slightly different technical and engineering problems. 
The purpose of this section will be twofold. First, the published and readily accessible literature on brine chemistry, geochemistry, and related engineering problems in the Salton Sea KGRA will be reviewed, and, second, published chemical analyses of the wells listed in Table 1 will be tabulated for easy conparison. The literature review in this section will be restricted to papers that are concerned only with the Salton Sea field. In following sections, references will be made to papers that are relevant to Salton Sea brine chemistry but are not concerned exclusively with the Salton Sea field. Hopefully, the tabulation of chenical analyses will illustrate the variation in chemical composition of geothermal brines and the lack of uniform analytical procedures.

The Salton Sea geothermal literature is limited in quantity and scope. Much of the valuable engineering and physical chemistry data has not been published in the open literature and remains in closed files. The geochemistry, however, has received more attention, especially in the areas of metasomatic processes and isotopic composition studies.

The history of geothermal development in the Salton Sea KGRA up to 1975 is thoroughly covered in a paper by Palmer, et al. ${ }^{5}$ which was originally intended as a guidebook for a tour sponsored by the Second United Nations Symposium on Geothermal Development. Additional sources for historical information are reports issued by the California Department of Conservation, Division of Mines and Geology. 5,23-25

An overview of geothermal resources, technical problems, and brine quality can be obtained from papers by Blake, ${ }^{26}$ Dutcher, et al., ${ }^{27}$ Goldsmith, ${ }^{28}$ Rex, $^{29}$ Werner and 0lson, 30 and White and Yates. 31 Information in these papers is not presented in a rigorous scientific fashion, but it. is sufficient as an introduction to various facets of the Salton Sea field.

Four fundamental papers, two by Helgeson 15,32 and two by White et a1. ${ }^{7,16}$ form the cornerstone of brine chemistry papers for the Salton Sea KGRA. The 1963 paper by White, et al. ${ }^{7}$ which appeared in Science, presents 
basic information about the physical and chemical characteristics of the drilling and production of I.I.D. 非. The problem of scale formation and composition is also treated. In their later paper, White, et al. ${ }^{16} \mathrm{ex}-$ amined the brine and scale of I.I.D. \#1 in much greater detail. They determined that the brines are in equilibrium with an assemblage of sulfide minerals in the reservoir rocks and that the scale which deposited in enormous quantities was primarily amorphous silica with relatively high percentages of iron-, copper-, and silver-containing sulfides. Helgeson ${ }^{15,32}$ presents some interesting analytical results on the chemical composition and thermodynamic characteristics of the geothermal reservoir. The chemical composition (Table 2) for I.I.D. \#2 and State \#1 represent the average values of several hundred analyses, but regrettably there is no mention of the analytical procedures used to obtain these values. Some important points made by the author are that the relative concentrations of dissolved solids should vary slightly from well to well, and that a concentration gradient exists across the field with a maximum at the center of the anomaly and a minimum near peripheral regions. Moreover, the observed silica concentrations appear to be consistent with quartz saturation at $300^{\circ} \mathrm{C}$.

A spate of papers, which were concerned with topics such as the origin of heavy metals, metamorphism of sediments, source of fluids, origin of $\mathrm{CO}_{2}$, isotopic composition of the brines, and mercury and base metal deposits, appeared from 1965-1969. $34-41$ The majority of these papers are authored or coauthored by Donald White of the U.S. Geological Survey, and they have a strong geological-geochemical emphasis with little practical information relevant to brine chemistry or production technology.

Literature on corrosion studies relevant to the Salton Sea environment is relatively non-existent. This is understandable in light of the uncertain economic prospects for utilization of the brine and its extremely corrosive nature. Before metal-producing companies will make a commitment to corrosion research and materials development, a true geothermal energy market must be shown to exist. In the absence of current industrial research, the U.S. Bureau of Mines has conducted preliminary 
TABLE 2

Chemica1 Composition of Geothermal

Brines from Salton Sea KGRA Wells

ppm concentrations (except pH)

\begin{tabular}{|c|c|c|c|c|c|c|}
\hline$\frac{\text { We11 }}{\text { Date }}$ & $\frac{\text { Pioneer \#3 }}{5-29}$ & $\frac{\text { I.I.D. \#I }}{3-62}$ & $\frac{\text { I.I.D. \#1 }}{5-62}$ & $\frac{\text { I.I.D.非 } 1}{1-63}$ & $\frac{\text { I.I.D. 非 } 1}{4-66}$ & I.I.D. \#2 \\
\hline \multicolumn{7}{|l|}{ E1ement } \\
\hline Sodium & 20,400 & 55,000 & 76,000 & 51,000 & 50,400 & 53,000 \\
\hline Potassium & & 18,200 & 29,900 & 24,000 & 17,500 & 16,500 \\
\hline Lithium & & & & 300 & 215 & 210 \\
\hline Barium & & & & 200 & 235 & 250 \\
\hline Calcium & 16,000 & 30,500 & 34,430 & 40,000 & 28,000 & 27,800 \\
\hline Strontium & & & & 740 & 609 & 440 \\
\hline Magnesium & 4,000 & & 486 & 35 & 54 & 10 \\
\hline Boron & & 745 & 432 & 520 & 390 & 390 \\
\hline Silica & & 10 & 26 & 110 & 400 & 400 \\
\hline Iron & & 2,000 & 3,416 & 3,200 & 2,090 & 2,000 \\
\hline Manganese & & 1,300 & 30 & 2,000 & 1,560 & 1,370 \\
\hline Lead & & & & 104 & 84 & 80 \\
\hline Zinc & & & & 970 & 790 & 500 \\
\hline Copper & & & & 10 & 8 & 3 \\
\hline Silver & & & 1 & & & 1 \\
\hline Rubidium & & & & 168 & 137 & 70 \\
\hline Cesium & & & & 22 & 16 & 20 \\
\hline Chloride & 68,000 & 168,000 & 200,000 & 185,000 & 155,000 & 155,000 \\
\hline$\Sigma \mathrm{CO}_{2}$ & 300 & & & & 150 & 500 \\
\hline$\Sigma S^{2}$ & 200 & 30 & & & 21 & 30 \\
\hline $\begin{array}{l}\mathrm{pH} \\
\text { TDS }\end{array}$ & 6.5 & $278 \begin{array}{r}3.9 \\
000\end{array}$ & 5.1 & & 5.2 & \\
\hline $\begin{array}{l}\text { TDS } \\
\text { REF }\end{array}$ & $\begin{array}{r}110,000 \\
45\end{array}$ & $\begin{array}{r}278,000 \\
46\end{array}$ & $\begin{array}{r}340,000 \\
46\end{array}$ & $\begin{array}{r}319,000 \\
34\end{array}$ & $\begin{array}{r}258,000 \\
16\end{array}$ & $\begin{array}{r}259,000 \\
15\end{array}$ \\
\hline
\end{tabular}

continued 
Table 2 continued

\begin{tabular}{|c|c|c|c|c|c|c|c|}
\hline$\frac{\text { We1I }}{\text { Date }}$ & $\frac{\text { I.I.D. } \# 3}{3-65}$ & $\frac{\text { Sinc \# } 3}{4-62}$ & $\frac{\text { Sinc } \# 3}{4-63}$ & $\frac{\text { Sinc } \# 4}{6-64}$ & $\frac{\text { Sinc 非 } 4}{7-67}$ & $\frac{\text { Sport \#1 }}{8-61}$ & State 非 \\
\hline$\overline{\text { Element }}$ & & & & & & & \\
\hline $\mathrm{Na}$ & 10,600 & 36,340 & 50,600 & 78,000 & 58,443 & 70,000 & 47,800 \\
\hline $\mathrm{K}$ & 1,250 & 7,820 & 13,200 & 20,690 & 14,918 & 24,000 & 14,000 \\
\hline$L i$ & 40 & & 49 & 80 & 287 & 150 & 180 \\
\hline $\mathrm{Ba}$ & 3 & 540 & 570 & & & & 190 \\
\hline $\mathrm{Ca}$ & 1,130 & 14,550 & 23,000 & 37,735 & 26,992 & 34,470 & 21,200 \\
\hline Si & 85 & 360 & 510 & & 610 & & \\
\hline $\mathrm{Mg}$ & 74 & 780 & 1,940 & 2,225 & 736 & 18 & 27 \\
\hline B & 100 & 210 & & & 332 & 149 & 290 \\
\hline $\mathrm{SiO}_{2}$ & 120 & & & 625 & 90 & 5 & \\
\hline $\mathrm{Fe}$ & 1 & & & & 1,200 & 4,200 & 1,200 \\
\hline Mn & 6 & 410 & 1,000 & & 2,000 & & 950 \\
\hline $\mathrm{Pb}$ & & 80 & 200 & & 70 & & 80 \\
\hline $\mathrm{Zn}$ & & & & & 600 & & 500 \\
\hline $\mathrm{Cu}$ & & 0 & 1 & & 6 & & 2 \\
\hline $\mathrm{Ag}$ & 2 & 0 & 0 & & 1 & & 1 \\
\hline $\mathrm{Rb}$ & & & & & & & 65 \\
\hline Cs & & & & & & & 17 \\
\hline $\mathrm{CI}^{-}$ & 19,700 & 93,650 & 141,500 & 210,700 & 154,590 & 201,757 & 127,000 \\
\hline$\Sigma \mathrm{CO}_{2}$ & 1,880 & & & & & & 5,000 \\
\hline$\Sigma \mathrm{S}$ & 621 & 58 & 0 & 75 & 19 & 34 & 30 \\
\hline $\mathrm{pH}$ & 7.5 & 5.3 & 4.3 & 5.0 & 5.0 & & \\
\hline TDS & 35,600 & 183,700 & 276,000 & 387,500 & 266,560 & 334,987 & 219,500 \\
\hline REF & 38 & 46 & 46 & 46 & 30 & 6 & 15 \\
\hline
\end{tabular}

\begin{tabular}{|c|c|c|c|c|c|}
\hline$\frac{\text { We11 }}{\text { Date }}$ & $\frac{\operatorname{Sinc} \# 4}{7-74}$ & $\frac{\text { Sinc } 1 \equiv 4}{9-74}$ & $\frac{\text { Sinc \#促 }}{10-74}$ & $\frac{\text { Sinc } \# 4}{10-74}$ & Magmax 非 \\
\hline$\frac{\text { Lemenl }}{\mathrm{Na}}$ & 53,800 & 52,000 & 46.600 & 52,500 & 52,500 \\
\hline $\mathrm{K}$ & 18,000 & 13,300 & 12,400 & 13,700 & 5,000 \\
\hline \multicolumn{6}{|l|}{$\mathrm{Li}$} \\
\hline \multicolumn{6}{|l|}{$\mathrm{Ba}$} \\
\hline $\mathrm{Ca}$ & 26,300 & 20,200 & 22,200 & 23,400 & 25,000 \\
\hline $\mathrm{Si}$ & & & & & 36 \\
\hline \multicolumn{6}{|l|}{$\mathrm{Mg}$} \\
\hline B & & & & & 500 \\
\hline $\mathrm{SiO}_{2}$ & & & & & 500 \\
\hline \multicolumn{6}{|l|}{$\mathrm{Fe}$} \\
\hline & & & & & 200 \\
\hline $\mathrm{Zn}$ & & & & & \\
\hline \multicolumn{6}{|l|}{$\mathrm{Cu}$} \\
\hline \multicolumn{6}{|l|}{$\mathrm{Ag}$} \\
\hline \multicolumn{6}{|l|}{$\mathrm{Rb}$} \\
\hline \multicolumn{6}{|l|}{ Cs } \\
\hline \multicolumn{6}{|l|}{$\mathrm{Cl}^{-}$} \\
\hline \multicolumn{6}{|l|}{$\mathrm{\Sigma CO}_{2}$} \\
\hline \multicolumn{6}{|l|}{$\Sigma S$} \\
\hline \multicolumn{6}{|l|}{$\mathrm{pH}$} \\
\hline \multicolumn{6}{|l|}{ TDS. } \\
\hline REF & 47 & 47 & 47 & 47 & 48 \\
\hline & & & -18 & & \\
\hline
\end{tabular}


Table 2 continued

\begin{tabular}{|c|c|c|c|}
\hline$\frac{\text { We11 }}{\text { Date }}$ & $\frac{\text { Woolsey 非1 }}{2-72}$ & $\frac{\text { Woolsey \#1 }}{3-72}$ & $\frac{\text { Woolsey \#I }}{3-72}$ \\
\hline \multicolumn{4}{|l|}{ Element } \\
\hline $\mathrm{Na}$ & 49,257 & 28,195 & 49,729 \\
\hline K & 2,881 & 3,055 & 6,510 \\
\hline $\mathrm{Li}$ & 65 & 63 & 90 \\
\hline \multicolumn{4}{|l|}{$\mathrm{Ba}$} \\
\hline $\mathrm{Ca}$ & 8,550 & 7,284 & 12,658 \\
\hline \multicolumn{4}{|l|}{$\mathrm{Sr}$} \\
\hline $\mathrm{Mg}$ & 651 & 113 & 136 \\
\hline \multicolumn{4}{|l|}{$\mathrm{B}$} \\
\hline $\mathrm{Si}$ & 112 & 141 & 181 \\
\hline $\mathrm{Fe}$ & 84 & 141 & 244 \\
\hline Mn & 121 & 150 & 488 \\
\hline \multicolumn{4}{|l|}{$\mathrm{Pb}$} \\
\hline \multicolumn{4}{|l|}{$\mathrm{Zn}$} \\
\hline \multicolumn{4}{|l|}{$\mathrm{Cu}$} \\
\hline \multicolumn{4}{|l|}{$\mathrm{Ag}$} \\
\hline \multicolumn{4}{|l|}{$\mathrm{Rb}$} \\
\hline \multicolumn{4}{|l|}{ Cs } \\
\hline $\mathrm{Cl}$ & 59,015 & 49,342 & 81,183 \\
\hline \multirow{2}{*}{\multicolumn{4}{|c|}{$\begin{array}{l}\mathrm{SCO}_{2} \\
\Sigma \mathrm{S}\end{array}$}} \\
\hline & & & \\
\hline TDS & 120,735 & 88,484 & 153,219 \\
\hline pH & $\begin{array}{r}6.2 \\
89\end{array}$ & $\begin{array}{r}6.45 \\
89\end{array}$ & $\begin{array}{r}6.25 \\
. \quad 89\end{array}$ \\
\hline REF & 89 & - $\quad 89$ & 89 \\
\hline
\end{tabular}


corrosion studies on various steel alloys using synthetic brines and real brines from Magmamax 非1. After a laboratory, screening to determine the best corrosion-resistant materials which were comercially available, field tests under actual operating conditions were made. Results of initial work by the Bureau of Mines has been published. ${ }^{42-44}$ The best corrosion-resistant alloys appeared to be Hastelloy $\mathrm{C}-276$ and E-Brite 26-1, while 3I6L stainless and Carpenter 20 showed potential.

\section{Brine Analyses}

The chemical compositions of brine samples taken from wells in the Salton Sea KGRA are tabulated for convenience in Table 2. The sampling methods and analytical procedures vary from one well analysis to another; therefore, these numbers should be indicative of a concentration range and should not be considered to be very precise. As was previously pointed out by Helgeson, 32 "The brine compositions will vary from well to well, depending on the depth of production and the temperature of the different parts of the reservoir." Also the composition of a particular well may vary as a function of the total production time, the rate of flow, and the nature of the underlying sediments.

In the geochemical literature, attention to experimental detail, at least with Salton Sea chemical analyses, seems to be of minimal importance even in trace metal determinations. Concentrations of various elements have been determined by a variety of techniques, including atomic absorption spectrophotometry, arc atomic emission spectrographs, isotopic dilution (for $\mathrm{Pb}$ and $\mathrm{Sr}$ ) mass spectrographs, ion-selective electrodes, $\mathrm{X}$-ray fluorescence, and standard colorimetry. In most cases, corrections have been made for the steam losses. 
Current research efforts in the Salton Sea field are concentrated on the Sinclair wells $\# 3$ and $\# 4$ and on the Magmamax wells. A consortium, consisting of Phillips Petroleum Company, Southern Pacific Land Company, and Southern California Edison, was formed in 1972, and they subsequently acquired the rights to the Sinclair site. Their research and development program has the following goals: first, to establish a continuous and reliable production of geothermal brine and to develop a suitable reinjection system; second, to study the problems of scaling and corrosion and devise methods of control; third, to develop technology for power generation and mineral recovery from the high-temperature, hypersaline brines.

San Diego Gas and Electric began its research program on the Magmamax well site, which is approximately $1 / 2$ mile from the Sinclair site, in 1972. Leases were obtained from Magma Power Company and Magma Energy, Inc. Their primary interest is in the development of a binary cycle system for power generation. The geothermal brines would be used, after flashing, in a heat exchange system to vaporize iso-butane, which would then be used for the generation of electricity. Their research program also involves the study of scaling and corrosion.

Two additional organizations, Lawrence Livermore Laboratory and the U.S. Bureau of Mines, have been involved in geothermal research programs at the Sinclair and Magmamax sites, respectively. Lawrence Livermore Laboratory (LLL) has designed its research program around the total flow concept. 49 In this proposed system, the entire brine-steam mizture emerg ing from the wellhead is passed directly through a nozzle (convergingdiverging) expander. The resulting high-velocity jets are used to drive an impulse turbine and electrical alternator. Because of the mechanical. simplicity and design flexibility of this system, scale and corrosion control is expected to be simplified. The overall research goals of LLL involve: first, refinement, testing and evaluation of the total flow system; second, a detailed examination of brine chemistry and development of 
methods for scale and corrosion control; third, building and operating a $10 \mathrm{MW}$ pilot plant based on the total flow process. On the other hand, the research program of the U.S. Bureau of Mines is not comprehensive. They are concerned exclusively with the problem of corrosion in hypersaline brines, and their research goal is to find the best corrosionresistant metals and alloys available on the commercial market.

In the area of brine chemistry, the research programs differ significantly, although their ultimate goal of scale and corrosion control is the same. In the subsequent paragraphs, the brine chemistry research of each group will be sumarized.

In the words of $B$. W. Berthelot, who commented jocularly at a conference where geothermal operating difficulties were discussed, the threeparty consortium of Phillips, SPL and SCE "has been eminently successful in duplicating previous failures." Their initial research focused on actual we11 performance characteristics and the problems of scaling and corrosion. Scaling within the wellhead pipes was reduced significantly $\left(1 / 32^{\prime \prime}\right.$ deposited in five months) by choking back the well to the minimum point of stability necessary to maintain maximum wellhead temperature and pressure. In addition to pressure control, an attempt was made to control silica deposition by injecting ammonia and consequently altering the nature of the precipitation so that it failed to adhere to surfaces. Instead of scaling the problem then becomes one of waste disposal. Corrosion studies were run at State \#1 which had been shut in for six years. The bottom hole temperature of this well had been estimated ${ }^{15}$ to be $350^{\circ} \mathrm{C}$ and the TDS content was determined to be $219,000 \mathrm{ppm}$. None of the "space-age products", which were introduced into the well, exhibited pronising corrosion-resistant properties. SCE has subcontracted work to Atomics International, a division of Rockwell International Corporation, for cycle analysis, corrosion and scaling studies, and design of field equipment. Preliminary scale prevention studies are being conducted with synthetic brines in a controlled laboratory environment.

San Diego Gas and Electric has used an experimental engineering approach in an attempt to eliminate the problems of scaling and corrosion. 
During initial tests of their binary cycle system, heat transfer coefficients dropped drastically because of scale deposition on the walls of both the brine and steam heat exchangers. In 1974, a two-stage flash system consisting of stean separators, steam scrubbers, and heat exchangers was tested. The tests were carried out to determine if scrubbing the steam could successfully eliminate the scaling problem. The scrubbing system, designed by the Ben Holt Company of Pasadena, California, is based on a system original1y developed for dehydrating natural gas. In the present design, separated steam flows upward through a distillation-1ike column which has five trays of pure water. Wash water is added continuously through the top of the column and it cascades down. This is apparenty an efficient method of contacting small volumes of liquid with a vapor. In preliminary tests, ${ }^{50}$ the scrubbers washed about $15,0001 \mathrm{bs} / \mathrm{min}$. of steam with less than one quart/min. of wash water. The dissolved solids content of the steam was reduced from 200 to $20 \mathrm{ppm}$. Subsequent tests runs in the exchangers showed no scale problems occurred in the pipes and in the plumbing system between the scrubbers.

The Geothermal Energy Development Program at Lawrence Livermore Laboratory is engaged in brine chemistry research which is geared to the problem of scaling after nozzle expansion. Their research efforts have been divided into a chemistry subprogram, which is investigating the kinetics of silica precipitation, brine composition, and scale formation, and a materials subprogram, which is testing materials for corrosion resistance and suitability for use as turbine components. The chemistry and materials subprograms are being carried out at the Sinclair 4 site using brines under actual operating conditions.

A variety of metals and plastics were tested under field conditions by flowing brine through nozzles and over simulated turbine blades. Most materials scaled or eroded, but Teflon (PFA) withstood over 100 hours of flowing brine. A Scanning Electron Microscope was used to examine the final surface conditions. The PFA surface was slightly roughened, but suffered lictle erosion. In early field testing, polyphenylquinoxalinel carbon fiber, $P P Q-n e a t$, and polyimide samples were lowered to the bottom 
of the well in a perforated pipe. The PPQ-neat survived intact, the composite suffered delamination, and the polyimide became friable. Approximately 25 other polymerjc materials were tested for wear in synthetic brines at $300^{\circ} \mathrm{C}$ in a stainless steel bomb.

Sinclair 非 4 brine has been analyzed for $\mathrm{CO}_{2}$ content and for other noncondessable gases by mass spectrometry. The mixture of $\mathrm{CO}_{2}, \mathrm{~N}_{2}, \mathrm{CH}_{4}$, and hydrogen contains 98 percent $\mathrm{CO}_{2}$, and the total is less than one percent of the brine. 88 The brine has also been analyzed for $\mathrm{Na}, \mathrm{Ca}$ and $\mathrm{K}$, and these results are included in Table 2 .

Scale deposits which formed in a stainless steel nozzle during a five-day production run were analyzed using a scanning electron microscope. Three distinct metallic phases were formed. One phase is predominately metallic with $\mathrm{SiO}_{2}$ trapped in the interstices. $\mathrm{A} \mathrm{SiO}_{2}$ layer covered all three metallic phases.

The last phase of the current program involves an attempt to adapt a copy of PATHCAL, ${ }^{52}$ a complex Fortran IV program designed to calculate multiple equilibrium processes occurring in high-temperature, highpressure geologic systems. This program will allow a quantitative prediction of the extent to which minerals are either destroyed or produced and the resulting distribution of chemical species when an irreversible reaction takes place between a given mineral and an aqueous solution at constant temperature and pressure.

The research program of the U.S. Bureau of Mines has been summarized in the previous section, and the detailed results of their most recent Salton sea field experiments are available from reference 44. 
In the previous section, current brine chemistry research programs were discussed. In this section, summaries of proposed research, which would be relevant to the problems of scaling and corrosion, will be presented. Several engineering and research organizations have shown interest in the problem of geothernal scaling and corrosion, and several proposals are oriented toward the Salton Sea field. Hopefully, this section will illustrate the diverse approaches that may be taken to find a solution to scaling and corrosion problems. Moreover, a review of the varied research ideas will provide a background for recommending a preferred course of research that should result in the quickest possible solution to these problems. The section will be organized according to the proposing organization.

\section{Phillips, SPL and SCE}

SCE, ${ }^{53}$ in cooperation with Atomics International, has outlined a number of possible scale control methods. Their approach will be highly empirical. Some of the tentative methods they have outlined are inproved surfaces, ultrasonic energy, $\mathrm{pH}$ control, applied electxical potentials, chemical additives (i.e., tannins, polyelectrolytes, and sequestering agents), contact stabilization, and crystal seeding. SCE's approach to the corrosion problem is to use reports from other geothermal projects, from hot salt corrosion studies and from water desalination studies, as a guideIine for selecting materials which will be subsequently tested under laboratory and field conditions. They are optimistic about finding the most appropriate materials for the various phases of production using this approach.

Mineral recovery is another aspect of the SCE proposa1 which falls under the heading of brine chemistry and which has direct implications for scale control. It is proposed that minerals be extracted by a stepwise control of $\mathrm{pH}$. In the first stage, amorphous $\mathrm{SiO}_{2}$ and $\mathrm{Fe}(\mathrm{OH})_{2}$ would be removed. Further adjustment of $\mathrm{pH}$ combined with the introduction of air would result in the removal of manganese as $\mathrm{MnO}_{2}$. In the first two 
steps, lead and zinc will co-precipitate. Additional research is needed to economically extract lead and zinc. Following manganese removal, lithium recovery would be attempted. Lithium can be precipitated using an aluminum chloride solution as an aluminate, $\mathrm{Li}_{2}[\mathrm{(HO})_{3} \mathrm{AlOA}(\mathrm{OH}) 3^{1.54}$ Their process design calls for complete removal of scale-forming components by chemical txeatment followed by clarification and sludge removal. Design of model treatment facilities will have to take into account the variability of the brine composition as a function of production time.

The proposed research program follows a semi-empirical approach, but does not follow a rigorous scientific development. A number of scale control methods are discussed, and then it is stated: "Only one practical, economic, and effective method for scale prevention or control is required. With a large number of potentially effective methods, one can be optimistic that a practical method will be developed." One of SCE's promising methods of scale control, which is crystal seeding, has been tried in another form in the Wairakei geothermal field without success. At this stage, it is not certain where scaling will occur undex actual operating conditions or what the extent and rate of deposition will be when it does occur. This information seems to be necessary in order to devise a suitable scale control method. The SCE approach does not seem as satisfying as some other approaches, and would probably require much time and effort. Moreover, additional treatment similar to the proposed mineral recovery program may be necessary after steam separation and utilization to prevent possible clogging of discharge pipes and of the porous reservoir formation below the reinjection well.

\section{San Diego Gas and Electric - Ben Holt Co.}

A pragmatic engineering approach to the problem of scale and corrosion control is planned by the Ben Holt Co. for the $10 \mathrm{MW}$ power plant under construction at the Magmamax site. Scaling problems in heat exchangers have been eliminated by the scrubbing system described in the previous section. No additional research in the area of scale control is planned until the plant is operated over a reasonable period of time. 55 
This will allow the problem areas to be identified and suitable corrective measures to be planned. No research in the area of brine chemistry is planned. Their attitude is that it is too soon to worry about all the contingencies. In the addition to the present system, the Ben Holt Co. 56 has proposed the use of a direct contact binary cycle in which the working fluid is preheated, vaporized and superheated by direct contact with the geothermal hot water in a counter-current, liquid extraction colum. An advantage of this method would be the elinination of scaling on tubular surfaces used in conventional heat exchangers.

At the present stage in the development of geothermal resources in the Salton Sea KGRA, the Ben Holt Co. approach to scaling and corrosion seems to be reasonable. It is an efficient approach, since time will not be spent studying general brine chemistry in the hope of finding some information that would help in the design of scale control methods. Their approach is basically the same that has been recommended by H. C. Helgeson, R. O. Fournier, and F. A. MacDougall. If the goal is to generate power in the shortest time possible, the time and manpower necessary for a complete brine chemistry research program might be prohibitive.

\section{Lawrence Livermore Laboratory (LLL)}

In a sense, the approach that LLL has proposed is similar to the Holt plan, although they emphasize a combination of engineering and applied chemistry. Their research plan calls for an initial study under actual operating conditions to identify the location and extent of scaling and corrosion. Once this has been accomplished, control measures will be devised. But, under their comprehensive plan, they will also continue basic research in the areas described in the preceding section. Strong emphasis will be placed on developing reliable and consistent analytical procedures for the chemical analysis of brines, on development of downhole sampling techniques, on kinetic studies of silica precipitation, on the determination of brine enthalpies, and on computer modeling of the complex chemical interactions occurring in high-temperature, hypersaline brines. Materials are being tested and future experiments will evolve as results are accumulated. 
Their research program appears to be fundamentally sound and well. organized. One might question the need for a completely new downhole sampling device. Downhole samplers have already been developed by Fournier, et al. ${ }^{57,58}$ and klyen, 59 and it should be possible to readily adapt one of these to the Salton Sea environment. Klyen's sample vessel features a breakoff tube sealed in series with a non-return valve for the collection of brine and gas samples from geothermal drillholes in New Zealand. This device has been operated successfully at $300^{\circ} \mathrm{C}, 150 \mathrm{~atm}$., and at depths of $1,220 \mathrm{~m}$. It has survived uncorroded in brines containing $300,000 \mathrm{ppm}$ $\mathrm{NaCl}$ and at a pH 2.5. In order to accurately determine the downhole chemical environment, a sample device of this type is necessary, especially when there is more than one production depth. Lack of reproducibility in chemical analyses of surface samples is due to, in part, difficulty in obtaining representative samples. 60

\section{Occidental Research Corporation}

Occidental Research Corporation ${ }^{61}$ of La Verne, California, a subsidiary of Occidental Petroleum Corporation, has submitted a proposal to the Energy Research and Development Administration, entitled "Scale Deposition and Control in Geothermal Utilization Process Flants." Occidental proposes to study, both experimentally and theoretically, the deposition of silica and calcite scale using real geothermal brines under actual process conditions. This proposal is based on information gathered by Occidental in a study sponsored by the office of Saline Water to study silica scale control in geothermal brines. ${ }^{62}$. Their goal is to determine the relationship between brine composition, process conditions, and scaling. With this infornation scale control methods would be devised.

The deposition of silica scale is a kinetically controlled process which depends on the chemistry and physical characteristics (i.e., fluid flow and turbulence) of the brines. In order to determine the rate and extent of silica deposition with real brines, Occidental proposes to construct an experimental unit consisting of eight process modules that would simulate the various basic elements of a real geothermal plant. Each 
process module would be, in effect, a chemical reactor that would be monitored closely for changes in chemical composition, pH, temperature, pressure, flow rate, heat flux, and electrical conductivity. To duplicate the variety of process conditions that a geothermal brine would be subjected to, the process modules would include a flash tank and separator, a pressure drop without vapor liquid separation, a tee and flow ratio control, a tee and flow ratio control with combining tee, a holdup loop, a holdup tank, a packed bed-reinjection simulator, and a shell and tube heat exchanger. In addition to following the kinetics of silica deposition under simulated process conditions, they will examine in detail the brine composition as a function of time and the physical and chemical properties of the scale deposit. Standard analytical procedures would be used to determine brine composition and scale morphology. Another interesting feature of the Occidental proposal is a modular on-line monitoring system that would be compatible with the process unit modules. A computerized control and data acquisition system would be used to record data on magnetic tape for subsequent analysis. The sensors to be considered for the continuous monitoring system would measure pressure, temperature, conductivity, resistivity, $\mathrm{pH}$, redox potential, specific ion activities, optical transmittance, and $\mathrm{X}$-ray fluorescence.

Another phase of their proposed plan of research involves a laboratory study of the kinetics and mechanism of silica polymerization and colloid formation. Synthetic brines will be used to examine the effects of metal ions and hydroxide hydrosols on silica deposition rates. From experimental data, a model predicting the effect of flow conditions on nucleation and growth rates of silica agglomerates would be developed. This model would be based on previous models developed by Wahl 63,64 to predict the growth of $\mathrm{TiO}_{2}$ agglomerates. A model of this type would be useful to predict whether a silica precipitate will remain in the liquid or deposit on a pipe well. 
The Occidental proposal seems well founded. However, the geothermal group at Lawrence Livermore Laboratory has already initiated a scale study program which is similar in many respects to the Occidental proposal, but some important aspects of the occidental proposal are not covered by the LLL research program. Although the Occidental program is designed primarily for medium salinity brines such as those of the lower Imperial Valley, their intention was to make the proposal general enough so that it would also be applicable to the high-temperature, hypersaline brines. 65

A Recommended Research Program in Geothermal Chemistry ${ }^{66}$

"A Recommended Research Program in Geothermal Chemistry" was the result of an ad hoc meeting of academic and government laboratory researchers in June 1975, held at the Lawrence Berkeley Laboratory. Their task was to discuss the problems which hinder geothermal exploitation and to recomend a program for acquisition of chemical data and knowledge that would help solve some of the technical problems. Their report is not intended for a specific geothermal area or a specific set of developmental problens. The recommended program has a fundamental scientific framework designed to accumulate basic chemical data and to facilitate a better understanding of geothermal processes.

Five general areas were designated for concentrated study. These were: first, themodynamic and physical properties of geothermal solutions, minerals and metals; second, kinetics of chemical reactions and deposition; third, collection, evaluation and dissemination of physical and chemical data; fourth, natural systems and rock-water interactions; fifth, theoretical modeling of geothermal systems. The recommended research program would require the efforts of many scientists, but offers no guarantee that any of the technological problems would be solved in an engineering sense. The proposed research program is not designed to provide for the quickest. practical solution to problems of corrosion, scaling, environmental hazards, mineral extraction, or resource evaluation and exploration. 
Some of the more important and practical recomendations of the group will be 1isted. In the category of kinetics they recommend the following: a detailed study of the kinetics of polymertation of monomeric silica; a search for additives to inhibit nucleation and crystal growth; a study of the effect of crystal seeding to circumvent the nucleation step and accelerate crystal. growth; a study of how the shape and composition of equipment surfaces affects the attachment of a solid. In the category of analytical chemistry, they recommend the use of neutron activation, $X-r a y$ fluorescence, Zeeman-effect atomic absorption, and emission spectroscopy to determine elemental concentrations in brines and evaporites. And, finally, in the category of theoretical modeling of geothermal systems, they strongly recomend a computer modeling program, similar to Helgeson's 52 PATHCAI, to predict the various chemical interactions that could occur given an empirically determined analysis of elemental constituents.

The net effect of this recommended program was to outline suitable areas of academic research that would complement an on-going development program, but would probably do little to promote rapid utilization of geotherma1 resources in the Salton Sea KGRA. 
The major deterrent to commexcial exploitation of the Salton sea brine is definitely the problem of silica scaling, thus it is appropriate to review some aspects of basic silica chemistry. Following this review of classical silica chemistry, some current research and potential silica scaling control methods will be sumbarized.

\section{Chemistry Background}

The crust of the earth consists primaxily of metal silicates. Silicon and oxygen account for approximately 75 percent of the earth's crust. These two elements and the six next most abundant elements (0-46.60\%, Si-27.27\%, $\mathrm{Al}-8.13 \%, \mathrm{Fe}-5.00 \%, \mathrm{Ca}-3.63 \%, \mathrm{Na}-2.83 \%, \mathrm{~K}-2.59 \%, \mathrm{Mg}-2.09 \%$ ) 67 are usually found in the form of silicates. Elemental silicon reacts with oxygen at high temperatures to form silicon dioxide, $\mathrm{SiO}_{2}$, or as it is more commonly known, silica. Silica exists as a three-dimensional network solid of enormous stability. In nature, silica exhibits a variety of polymorphic crystalline forms and amorphous modifications. In cristobalite, a high-temperaw tuxe form of silica, the silicon atoms are arranged similarly to carbon atoms in dianond, except that oxygen atoms lie midway between them. Quartz, which is a slight modification of cristobalite, is the most familiar form of silica.

The basic structural unit of most silicate minerals is the $\mathrm{SiO}_{4}$ tetrahedron. Silica tetrahedra can occur singly, or by sharing oxygen corners they can occux in sma11 groups, in cyclic groups, in infinite chains or in infinite sheets. ${ }^{68}$ Amorphous silica found in natural deposits can range from soft hydrated gels to a hard, dense form of $\mathrm{SiO}_{2}$ known as opal. opaline silica occurs mainly in skeletal components of planktontc organisms and sponges, but it is found in deposits around hot springs and geysers. opal is a disordered form of silica consisting of an aggregate of submicroscopic crystallites of cristobalite with intercrystalline water. ${ }^{69}$ Water content ranges from 3 to 10 percent. Dissolved silica below pH 9 is present in solution only as monomeric silicic acid. 70

$$
\mathrm{SiO}_{2}+2 \mathrm{H}_{2} \mathrm{O} \neq \mathrm{H}_{4} \mathrm{SiO}_{4}(\mathrm{aq})
$$


Above $\mathrm{pH} 9, \mathrm{H}_{4} \mathrm{SiO}_{4}$ dissociates to give $\mathrm{H}_{3} \mathrm{SiO}_{4}{ }^{-m}$ and $\mathrm{H}_{2} \mathrm{SiO}_{4}=$

$$
\begin{aligned}
& \mathrm{H}_{4} \mathrm{SiO}_{4} \lessgtr \mathrm{H}_{3} \mathrm{SiO}_{4}^{-}+\mathrm{H}^{+} \\
& \mathrm{H}_{3} \mathrm{SiO}_{4} \neq \mathrm{H}_{2} \mathrm{SiO}_{4}=+\mathrm{H}^{+}
\end{aligned}
$$

In the geothermal brines of the Salton Sea KGRA, $\mathrm{H}_{4} \mathrm{SiO}_{4}$ should be the only silica species in solution, but when the brines become supersaturated silicic acid polymerizes with the elimination of water to form disilicic acid, $\mathrm{H}_{6} \mathrm{Si}_{2} \mathrm{O}_{7}$. Additional monomers can be added with the elimination of water to give polysilicic acids. A general equation for polymerization can be written as

$$
\mathrm{n} \mathrm{Si}(\mathrm{OH})_{4} \leftrightarrows\left(\mathrm{SiO}_{2}\right)_{\mathrm{n}}+2 \mathrm{nH}_{2} \mathrm{O}
$$

Polymerization involves the condensation of silanol groups ( $\mathrm{SiOH}$ ) to form. siloxane bonds. (Si-O-Si). ${ }^{17}$ Continued siloxane bond formation in three dimensions results in the formation of a colloidal silica particle. In concentrated solutions, the colloidal particles will aggregate to form a strong, firm gel, and in dilute solutions the particles will aggregate to form a weak gel or precipitate.

The solubility of amorphous silica and quartz has been studied extensively, ${ }^{11,71}$ A summary of the results of numerous investigators are presented in papers by Krauskopf 71 and Fournier and Rowe. ${ }^{11}$ The concentration of dissolved silica was determined in each case by a colorimetricammonium molybdate method. 72,73 The solubility of amorphous silica is significantly higher than that of quartz, but both exhibit similar temperaw ture dependencies. Geothermal brines are formed from hot water in equilibrium with various mineral silicates and the quartz which is released dis solves to give $\mathrm{H}_{4} \mathrm{SiO}_{4}{ }^{12,74}$ The $\mathrm{H}_{4} \mathrm{SiO}_{4}$, quartz equilibrium is the basis of a chemical method for estinating downole temperatures. It is assumed that the brine reaches the surface by an adiabatic isoenthalpic expansion of the original high-temperature water to a water and steam mixture. Consequently, the concentration of dissolved silica at the surface will be 
indicative of the temperature of the last equilibrium of the solution with quartz. This method is based on the metastability of a supersaturated siljea solution.

A silica solution can be prepared by ading reagent grade bodiun silicate to distilled water. A clear solution with a relatively high pH results because of hydrolysis of the silicate to form $\mathrm{H}_{4} \mathrm{SiO}_{4}$. If this solution is allowed to stand, an opaque precipitate will form within a day. Mononeric silica condenses slowly" at room temperature to form poly meric and colloidal silica. Above $\mathrm{pH}$ 9, the solubility of silica increases significantly 71,75 as oxthosilicic acid dissociates. Acidification of a sodium silicate solution will result in the formation of colloidal silica followed by further condensation to form an extensive gelatinous mass of silica. The gelatination of collotdal silica involves no noticeabje themal effect. 17 Gel formation cccurs when colloidal particles coalesce with the formation of siloxane cxoss-linkages. During this process water intrudes into micelles and an increase in viscostty results. As the gel ages, further cross-linkage occurs and some of the water is expelled. Eventually the gel hardens trapping some water. The hardened gel is known as opaline silica. If strong flocculating agents such as $\mathrm{Fe}^{=3}$ or $\mathrm{Al}^{+3}$ axe present in a collotdal silica suspension, the particles will aggregate and form a precipitate instead of a gel. The of groups on the surface of colloidal silica are weakly acidic. The dissociatlon of $-S i O H$ to give $-510^{-}$results in a negatively charged particle. When positively charged colloids such as $\mathrm{Al}_{2} \mathrm{O}_{3}$ or $\mathrm{Fe}_{2} \mathrm{O}_{3}$ are mixed with silica sols, the negatively charged silica sols are adsorbed. Iventual1y, the mixture passes through an isoelectrfc range in which coagulation or precipitation readily occurs. 76

The precipitation of silica from a supersaturated solution in the absence of catalytic influences can take several days or even weeks to reach equilibrium at $25.0^{\circ} \mathrm{C}, 71$ Geothemal brines saturated with silica can flow from a well clear, but, after standing at ambient conditions for a few hours, silica sols will form and eventually precipitate. The rate of gel formation is a strong function of $\mathrm{pH}$. Gelling is decelerated at 
low or high pel with maximum rates occurring in the pH range $4-7.17$ Dissolved electrolytes increase the rate of polymerization and coagulation of silica. Also, higher levels of initial supersaturation result in a faster precipitation to reach an equilibrium value.

\section{Genera1 Silica References}

Basic reference sources for background information on silica are the books of Iler, ${ }^{17}$ Vail $^{76}$ and Eite1. 77 . Iler and Eitel are basic academic reference sources which depend heavily on the 1iterature available before the date of publication. Vail's book is a two-volume compendium covering both the chemistry and the industrial uses of soluble silicates. A comprehensive bibliography of the experimental literature on silicate solubilities and reactions can be found in the office of Saline Water Progress Report No. 307. 78 This report contains short discussions and annotated bibliographies of papers covering the topics of analytical chemistry of silicates, of diagenesis and weathering, of hydrothermal reactions, of acid-base properties, and of corrosion prevention.

\section{Current Research on Silica in Geothermal Systems}

Research on silica systems is currently being carried out at Pensylvania State University by H. L. Barnes and co-workers. They are studying the kinetics of dissolution and precipitation of silica, and investigating the effect of surface energy, temperature and ionic strength on silica scaling. They have concluded the high ionic strength and high TDS will lower the equilibrium concentration of quartz in a brine system. However, their calculations of quartz solubility curves as a function of the activity of water are not consistent with experimental results of Hitahara ${ }^{79}$ or with results of Lawrence Livernore Laboratory experiments on Sinclair \#4. 33 In addition to solubility measurements, Barnes and co-workers are experimenting with ammonia injection to control pH and with sodiura addition to compex the silica. They have concluded that silica precipitation cannot be prevented, but that it should be possible to control where precipitation will occur. 
The first ionization constant of silicic acid has been redetermined recently by seward 80 for solutions up to $350^{\circ} \mathrm{C}$. At $130^{\circ} \mathrm{C}, \mathrm{pKa}_{1}$ for $\mathrm{H}_{4} \mathrm{SiO}_{4} \neq \mathrm{H}_{3} \mathrm{SiO}_{4}^{-}+\mathrm{H}^{+}$is 8.88 and at $350^{\circ} \mathrm{C} \mathrm{pKa}{ }_{1}=10.06$. The only species detected in a silica solution obtained from quartz were $\mathrm{H}_{4} \mathrm{SiO}_{4}, \mathrm{H}_{3} \mathrm{SiO}_{4}^{-}$, and $\mathrm{NaH}_{3} \mathrm{SiO}_{4}$. The stability constant, $B$, for ion pair formation between $\mathrm{Na}^{+}$and $\mathrm{H}_{3} \mathrm{SiO}_{4}^{-}$ranged from $10^{1.18}$ to $10^{1.40}$ for the temperature range $135-301^{\circ} \mathrm{C}$. Analysis for soluble silica was performed by atomic absorption spectrophotometry.

\section{Silica Scale Control - In Practice}

Silica scaling from the discharge waters of the Wairakei geothermal field has been studied extensively by Mahon, et al., 81 and results of experiments on the removal of silica and arsenic by precipitation as useful calcium silicates has recently been published by Rothbaum and Anderton. 82 They have successfully treated the silica-laden discharge waters on Wairakei with slaked lime to produce a flocculant precipitate which consists primarily of hydrated calcium silicate. If arsenic has been pre-oxidized to the pentavalent state, it will co-precipitate with silica. The hydrated calcium silicate gel is separated in settling tanks. The cost of this chemical treatment process is approximately $\$ 20,000$ per annum, which is the same figure that was expended previously for mechanical1y cleaning the discharge drains.

Yanagase, et a1. ${ }^{83}$ have described a detailed series of experiments on silica deposition at the otake geothermal field in Japan. Experiments were initiated after a discharge pipe was blocked by silica deposits. Using a light scattering photometer, they were able to show that the growth of silica particles started five minutes after emergence from the weII and continued for approximately an houx. To control silica deposition they built a retention tank with a series of baffles. The discharge brines are flowed through the tank for an hour to prevent adhesion of colloidal silica. Some scale deposits on the inside walls of the retention cells near the entrance of the tank, but there is no evidence of scale deposition in the discharge pipes. Apparently, a non-adhesive colloidal silica is 
formed during this treatment, and filtering of these particles is not necessary. It has also been shown that agitation of hot water can rem duce scale adhesion. Similar methods are being employed at Ahuachapan-1 in San Salvador to prevent silica deposition in a disposal culvert. ${ }^{14}$ The silica concentration is $650 \mathrm{ppm}$ at $95^{\circ} \mathrm{C}$.

Ozawa and Fujii ${ }^{84}$ have reported that silica scale was successfu1ly removed from a wellhead in the Matsukawa filed by allowing the scale to react with concentrated $\mathrm{NaOH}$. The scale was completely removed in 30 minutes, although it was necessary to maintain high temperature and pressure. 
On the basis of the information presented in the preceding sections and considering the consensus opinion of many geothermal experts, it is now possible to recommend a preferxed program of brine chemistry research. Any reasonable program will be designed to provide an understanding of the scaling and corrosion phenomenon and through this understanding develop methods or select materials that will minimize these problems. Where one proposed program will differ from another is in the approach to solving these problems. There appear to be three separate approaches to solving problems related to the chemical nature of the brines. They are: first, a trial and error engineering approach using a demonstration plant to identify the actual problems of operation before designing and resting specific solutions; second, a program coordinating on-site development and laboratory research in the potential problem areas, such as the kinetics of silica polymerization, colloid formation, aggregation and deposition; third, a program of research using synthetic brines under controlled laboratory conditions to isolate and study factors affecting corrosion and scaling and to develop suitable theoretical models that would be applicable to more than one situation. If the goal of government funding agencies is simply to promote the nost rapid developnent of geothermal resources in the Salton Sea KGRA, then the trial and error engineering approach is the preferred course of research. In this case, funds should be devoted to demonstration-type grants for pilot plant development and operation.

An example of the engineering approach is the work of the Ben Holt Company for San Diego Gas and Electric on the Magmamax site. Initially an expeximental binary cycle process was put on line, but operation was curtailed because of excessive scale deposition on heat exchanger surfaces. After considering the nature of the problem, the system was redesigned and a steam scrubber was added. This addition effectively eliminated the scaling problem and the results were so encouraging that a $10 \mathrm{NW}$ binary heat exchange loop is currently under construction. The Ben Holt Company is optimistic about future success, and they see little need for a comprehensive brine chemistry program in order to successfully generate power 
on a long-term basis. Another approach has been endorsed enthusiastically by H.C. Helgeson ${ }^{22}$ and R. O. Fournier ${ }^{85}$ as the only economical and realistic way to solve the problems of scaling and corrosion. Helgeson has based his opinion on his own personal experience with the Shell Development Company wells, I.I.D. 非 and State $\# 1$. He recomends construction of an acutal pilot plant operation and then carefully documenting the nature and location of scaling and corrosion. After isolating the problems, suitable control techniques can be devised. An applied engineering program should also include a rigorous logging of well characteristics and repeated chemical analyses of the brines, so that scaling and corrosion data can be correlated with any changes in brine composition or flow characteristics. One task that is also necessary in this regard is the development of reliable sampling and sample storage techniques. If a concurrent program of mineral extraction is feasible, one problem of brine treatment before reinjection may also be solved.

The U.S. Bureau of Mines is currently conducting a corrosion research program using commercially available materials. Any future program could use their results as a basis for selecting construction materials at a particular site. Research directed toward identification of corrosionresistant materials should be continued on a new pilot plant site. Corrosion research is inherently a trial and error process.

The second approach to brine chemistry research is being followed by Lawrence Livermore Laboratory (LLL). They are attempting to integrate field studies with laboratory investigations, and this is probably the most scientifical1y satisfying program, incorporating both fundamental engineering and brine research. It would be difficult at this stage to offer any positive suggestions for an improved program.

Occidental Research Corporation proposes a similar integrated research program with subtle differences. Occidental, along with LLL, emphasizes the reed to study the kinetics of scale deposition in a rigorous fashion. A novel aspect of the Occidental proposal is the modular system of chemical reactors that would simulate various process conditions and would facilitate an on-line kinetic study. Ideally, both Occidental and LLL should be 
funded, even though their approaches and philosophy are similar. Results obtained from a particular well site may not be applicable to another site within the Salton Sea KGRA. It would be scientifically wise to have two groups working on similar problems, because the potential interaction and exchange of ideas that would result would in the long run make the entire geothermal program stronger.

The third approach to scaling and corrosion studies is exemplified by the AEC Report, "A Recommended Research Program in Geothermal Chemistry." This program of research outlines suitable areas for university or for government laboratories without serious time limitations. Many of the suggested research topics are of fundamental irportance in an academic sense, and many of these projects should be funded through an agency such as the NSF. None of the suggested projects are critical for actual utilization of geothermal resources in the Salton Sea KGRA.

To choose a preforred research approach, the goal must be clearly defined. If the sole goal is to accelerate the commerclal development of the Salton Sea KGRA, the research can be limited to the engineering approach typifled by the San Diego Gas and Electric proposal. If, however, more generally applicable results are sought, the integrated approach, as typified by the LII, and Occidental proposals, is preferred, * provided that the level of funding is sufficient for a thorough study. Demonstration grants should be awarded for field test facilities development and study, and they should not be restricted to only one well site or scientific group. After the facilities are built and put into operation, they should be used as chemical reactors to study the rates of scaling and corrosion. Once the system has been carefully chatacterized and analytical data collected, ex* periments should be devised to control any problems due to scaling or corrosion. Chemical analyses of the brine composition should be performed

*The SCE approach is intermediate between the SDG\&E and the ILL-Occidental approach. 
in a rigorous, careful and precise fashion using the best equipment available. Sampling techniques should be improved and standardized so that comparative analyses are meaningful. Any kinetic experiments should be carried out using real process brines because of the difficulty of preparing suitable synthetic brines and because minor trace elements may play a significant role. Determination of brine enthalples is of fundamental and practical importance and should be a primary objective even of the engineexing approach. 


\section{REFERENCES}

1. H. W. Diamond, "Testimony Before Geothermal. Resources Board," Compendium of Papers, Geothermal Hearing, October 1970, The Resources Agency, California.

2. F. A. MacDougal1, Shell Dil Company, Houston, Texas, personal communication (1975).

3. S. H. Rook and G. C. Williams, "Imperial Carbon Dioxide Gas Field": Calif. Div. Oil and Gas BuIl., 28, 12 (1942).

4. D. E. White, "Violent Mud-Volcano Eruption of Jake City Hot Springs, Northeastern California," Bull. Geol. Soc. Am., 66, 1121 (1955).

5. T. D. Palmer, J. H. Howard and D. P. Lande, "Geothermal Development of the Salton Trough, California and Mexico," UCRL-51775, p. 13 (1975).

6. J. R. McNict, "Explotacion and Development of Geothermal Power in California": Calif. Div. Mines and Geol. Spec. Rep't. 75, 45 pp (1963).

7. D. E. White, E. T. Anderson and D. K. Grubbs, "Geothermal Brine WelI: Mile-Deep Hole May Tap Ore-Bearing Magmatic Water and Rocks Undergoing Metanorphism," Science, 139, 919 (1963).

8. G. Marsh in "Material Problens Associated with the Development of Geothermal Energy Resources," ed. B. A. Hall for U.S. Department of the Interior, Bureau of Mines, Grant No. P0-150296, p. 10, May (1975).

9. B. W. Berthelot, Ibid., p. 12, May (1975).

10. H. Bishop, Ibid., p. 14. May (1975).

11. R. O. Fournier and J. J. Rowe, "The Solubility of Quartz in water in the Temperature Interval from 25 to $300^{\circ} \mathrm{C}$ " "Geochim. et. Cosmochim. Acta, 26, 1029 (1962).

12. R. O. Fourniex and $J$. J. Rowe, "Estimation of Underground Temperatures from the Silica Content of Water from Hot Springs and WetSteam Wel1s," Amer. J. Sci., 264, 685 (1966).

13. H. P. Rothbaum and B. H. Anderson, "Removal of Silica and Arsenic from Geothermal Discharge Waters by Precipitation of Useful Calcium Silicates," paper presented at the 2nd United Nations Symposium on the Development of Geothermal Resources, San Francisco, May 20-29 (1975). 
14. G." Cuellar, "Behavior of Silica in the Geothemal Waste Waters," Ibid (1975).

15. H. C. Helgeson, "Geologic and Thermodynamic Characteristics of the Salton Sea Geothermal System," Amer. J. Sci., 266, 129 (1968).

16. B. J. Skinner, D. E. White, H. J. Rose and R. E, Mays, "Sulfides Associated with the Salton Sea Geothermal Brine," Econ. Geol. 62, 316 (1967).

17. R. K. Iler, "The Colloid Chenistry of Silica and Silicates," Cornell. University Press, Ithaca, New York, p. 161 (1955).

18. A. P. Brady, A. G. Brown and H. Huff, "Polymerization of Aqueous Potassium Silicate Solutions," J. Colloid Sci., 8, 252 (1953).

19. M. Reed in "Material Problems Associated with the Development of Geothermal Energy Resourees," ed. B. A. Hall for U.S. Departinent of the Interior - U.S. Bureau of Mines, Grant No. PO-150296, p. 8 (1975).

20. H. H. Uhlig, "Corrosion and Corrosion Control," John Wiley \& Sons, Inc., New York (1963).

21. G. Butler and H. C. K. Ison, "Corrosion and its Prevention in Waters," Reinhold Publishing Corporation, New York, p. 76 (1966).

22. H. C. Helgeson, personal comunication (1975).

23. J. R. MeNitt, "Exploration and Development of Geothermal Power in California," Calif. Div. Mines and Geol. Spec. Rep't. 75, Revised (1965).

24. J. B. Koenig, "The Salton-Mexicali Geothermal Province," Calif. Div. Mines Geol., Min. Info. Ser. 20, 非 (1967).

25. Ibid., "Geotherma1 Resources," 21, \#2 (1968).

26. R. L. Blake, "Extracting Minerals from Geothexwal Brines," U.S. Buresu of Mines Information Circular 8638.

27. L. C. Dutcher, W. F. Hardt and W. R. Moyle, Jr., "Preliminary Appraisal of Ground Water in Storage with Reference to Geothermal Resources in the Imperial Valley Area, California," U.S. Geological Survey, Circular 649 (1972).

28. M. Goldsmith, "Geothermal Resources in California: Potential and Problems," Environmental Quality Laboratory, Report No. 5, California Institute of Technology, Pasadena, CA (1971). 
29. R. W. Rex, "Cooperative Geologica1-Geophysical-Geochemical Investigation of Geothermal Resources in the Imperial Valley of California," Report from University of California, Riverside - Educational Research Service (1971).

30. S. L. Werner and $\mathrm{L}$. J. Olson, "Geothernal Wastes and the Water Resources of the Salton Sea Area, "California Department of Water Resources, Bulletin No. 143-7 (1970).

31. C. R. White and P. J. Yates, "Water and Power from Geothermal Resources in California," California Department of Water Resources, Bullet No. 190 (1974).

32. H. C. Helgeson, "Solution Chemistry and Metanorphism," in Researches in Geochemistry, P. H. Abe1son, ed., 55, 379-385 (1967).

33. L. Owen and A. Lundberg, Lawrence Livermore Laboratory, personal communication (1975).

34. D. E. White, "Saline Waters of Sedimentary Rocks," Fluids in Subsurface Environments --. A Symposium, Menoir No. 4, Anerican Association of Petroleum Geologists (1.965).

35. D. E. White, "Mercury and Base-Metal Deposits with Associated Thernal. and Mineral Waters," in Geochemistry of Hydrothermal Ore Deposits, H. L. Barnes, ed., Holt, Rinehart and Winston, Inc., New York (1967).

36. B. R. Doe, C. E. Hedge and D. E. Wite, "Preliminary Investigation of the Source of Lead and Strontium in Deep Geothermal Bxines Underlying the Salton Sea Geothermal Area," Econ. Geol. 61, 462 (1966).

37. L. J. P. Mufflet and D. E. White, "Origin of $\mathrm{CO}_{2}$ in the Salton Sea Geothermal System," XXIII International Geological Congress, Prague A68, 17, 185-194 (1968).

38. L. J. P. Muffler and D. E. White, "Active Metamorphism of Upper Cenozoic Sediments in the Salton Sea Geothermal Field and the Salton Trough, Southeastem California," Geol. Soc. Amer. Bu11, 80, 157 (1969).

39. R. N. Clayton, L. J. P. Muffler and D. E. White, "Oxygen Isotope Study of Calcite and Silicates of the River Ranch No. 1 Well, Salton Sea Geothermal Field, California," Amer. J, Sci., 266, 968 (1968).

40. H. Craig, "Isotopic Composition and Origin of the Red Sea and Salton Sea Geothermal Brines," Science, 154, 1544 (1966).

41. H. Craig, "Discussion - - Source Fluids for the Salton Sea Geothermal Syster," Amer. J. Sci. 267, 249 (1969). 
42. J. P. Carter and S. D. Cramer, "Corrosion Resistance of Some Conmercially Available Metals and Alloys to Geothermal Brines," Corrosion Problems in Energy Conversion and Generation, Elect. Chem. Soc., p. 240-250, Oct. (1974).

43. S. D. Cramer, "The Solubility of Oxygen in Geothemal Brines," Ibid., p. 251-262, Oct. (1974).

44. P. B. Needham, Jr. and J. P. Carter, "Scaling and Corrosion Studies of Alloys Used as Construction Materials in the Inperial Valley Geothermal Brines," paper presented at Amer. Inst. of Mech. Eng., Feb. (1975).

45. California Department of Fish and Game, "A Biological Survey of the Salton Sea," 15, \#3 (1929).

46. Colorado River Basin Reglonal Water Quality Control Board, "Identification and Evaluation of Federal, State, and Local Interests in the Salton Sea, Californta," (1967).

47. A. L. Austin, "The Lawrence Livermore Laboratory Geothermal Energy Development Program Status Report," 14 February 1975, UCID-16721.

48. H. K. Bishop, paper presented at U.S. Bureau of Mines Workshop on "Material Problens Assoclated with the Development of Geothermal Energy Resources," 14-16 May 1975, Holtville, California.

49. A. L. Austin, G. H. Higgins and J. H. Howard, "The Total Flow Con" cept for Recovery of Energy from Geothermal Hot Brine Deposits," Lawrence Livernore Laboratory, Report UCRL-51366 (1973).

50. A. J. L. Hutchinson, Material Problems Associated with the Development of Geothermal Energy Resources," B. A. Hall, ed., for the U.S. Department of the Interfor - U.S. Bureau of Mines, Grant No. PO150296 - coples available fxom the Geothemel Resources Council, P.0. Box 1033, Davis, California 95616, p. 36, May (1975).

51. T. C. Hinrichs in "Geothermal Development of the Salton Trough, California and Mexico," ed. by T. D. Palmer, J. H. Howard and D. P. lande for ERDA, contract No, W-7405* Eng-48, UCRL-51775, p. 30-36, Apri1 (1975).

52. H. C. Helgeson, T. I. Brown, A. Nigrini and T. A. Jones, "Calculation of Mass Transfer in Geochemical Processes Involving Aqueous Solutions," Geochim. Cosmochim. Acta, 34, 569 (1970).

53. "Proposal to the National Sclence Founction for a Salton Sea Geothermal Experimental Program," submitted by the Southern Calffornia Edison Company, 27 January (1975). 
54. F. A. Cotton and G. Wilkinson, "Advanced Inorganic Chemistry," 3rd ed., Wiley-Interscience, p. 267 (1972).

55: A. J. L. Hutchinson, the Ben Holt Co., Pasadena, CA, personal communication (1975).

56. B. Holt and I. Sheinbaum, "Conceptual Design of a Direct Contact Binary Cycle Power Plant," in. Abstracts for the 2nd United Nations Symposium on the Development of Geothermal Resources, 20-29 May (1975).

57. F. 0. Fournier and A. H. Truesde11, "A Device for Measuring Downhole Pressures and for Sampling Fluids in Geothermal Wells, Prof. Paper U.S. Geol. Survey, 750-C, C146-C150 (197I).

58. F. O. Fournier and J. C. Morgenstern, ibids C151-155 (1971).

59. L. E. Klyen, "A Vessel for Collecting Subsurface Water Samples from Geothermal Driliholes," Geothermics, 2, No. 2, 57-60 (1973).

60. W. A. J. Mahon, "Sampling of Geothermal Drillhole Discharges," Proc. U.N. Conf. on New Sources of Energy, Rome, Italy, v. 2, G.46, 269$278(1964)$.

61. E. F. Wah1, F. T. Winters, R. D. Steward and I. K. Yen, "Scale Deposition and Control in Geothermal Utilization Process Plants," a proposal submitted to the Energy Research and Development Administration by Garrett Research and Development Company, Inc., LaVerne, California, April (1975).

62. E. F. Wahl, I. K. Yen and W. J. Bartel, "Silicate Scale Control in Geothermal Brines," final report to U.S. Department of the Interior office of Saline Water, Contract No. 14-30-3041, 1 September (1974).

63. E. F. Wah1 and C. G. Baker, "The Kinetics of Titanium Dioxide Agglomeration in Agitated Liquid Suspension," Can. J. Chem. Eng., 49, 742 (1971).

64. E. F. Wahl, G. G. Pangborn and H. A. McCurdy, "Dymanic Analysis and Mathematical Model of High-Speed Dispersion." J. Paint Tech. 44 , 98-107, (1972).

65. E. F. Wahl, personal communication (1975).

66. R. N. Lyon and G. A. Kolstad, eds., "A Recommended Research Program in Geothermal Chemistry," prepared by an Ad Hoc Comittee convened by the U.S. Atomic Energy Conmission, office of Information Service, Technical Information Center, WASH-1344, October (1974). 
67. B. E. Douglas and D. H. MacDaniel, "Concept and Models of Inorganic Chemistry," Blaisdell Publishing Co., Waltham, Mass., p. 129 (1965).

68. A. F. Wells, "Crystal Chemistry," 3rd ed., Oxford University Press, London, chp. 21 (1962).

69. C. Fronde1, "The System of Mineralogy," v. III, "Silica Minerals," 7th ed., Wiley, New York (1962).

70. R. Siever, "Low Temperature Geochemistry of Silicon," in "Handbook of Geochemistry," K. H. Wedepohl, ed., V. II-1, Springer-Verlag, Berlin (1971).

71. K. B. Krauskopf, "The Geothermistry of Silica in Sedimentary Environments," Soc. Econ. Paleontologists and Miner, Spec. Pub. \#1, 4-19 (1959).

72. K. A. Fanning and P. O. Pilson, "On the Spectrophotometric Determination of Dissolved Silica in Natural Waters," Anal. Chem., 45, 136 (1973).

73. H. M. Webber and A. L. Wilson, "The Absorptiometric Determination of Silicon in Water," Analyst, 94, 110 (1969).

74. W. A. J. Mahon, "Silica in Hot Water Discharge from Drillholes at Wairakei, New Zealand," N. Z. J. Sci., 9, 135 (1966).

75. G. B. Alexander, W. M. Heston and R. K. Ilex, "The Solubility of Amorphous Silica in Water," J. Phys. Chem., 58, 453 (1954).

76. J. G. Vail, "Soluble Silicates," v. 1, Reinhold, New York, p. 162 (1952).

77. W. Eitel, "The Physical Chemistry of the Silicates," University of Chicago Press, Chicago (1954).

78. A. G. Collins, "Silicate Reactions - A Review," U.S. Department of the Interior - Office of Saline Water, Report No, 307, 99 pp. (1968).

79. S. Kitahara, "The Solubility of Quartz in Aqueous Sodium ChIoride Solution at High Temperatures and High Pressures," Rev. Phys. Chem. Japan, 30, 115 (1960).

80. T. M. Seward, "Determination of the First Ionization Constant of Silicic Acid from Quartz Solubility in Borate Buffer Solutions up to $350^{\circ} \mathrm{C}$," Geochim. Cosmochim. Acta, 38, 1951 (1974).

81. W. A. J. Mahon, L. E. Klyen and G. D. McDowe11, "Silica Precipitation from Waters Discharged from Geothermal We11s," report from the Chemistry Division, Wairakei, New Zealand. 
82. H. P. Rothbaum and B. H. Anderton, "Removal of Silica and Arsenic from Geothermal Discharge Waters by Precipitation of Useful Calcium Silicates," paper presented at the 2nd United Nations Symposium on the Development and Use of Geothermal Resources, San Francisco, CA, 20-29 May (1975).

83. T. Yanagase, Y. Suginohara and $K$. Yanagase, "The Properties of Scales and Methods to Prevent Them," Geothermics, v. 2, part 2, 1619 (1970).

84. T. Ozawa and Y. Fujii, "A Phenomenon of Scaling in Production Wells and Geotherma1 Power Plant in the Matsukawa Area, "Geothermics, v. 2, part 2, $1613(1970)$.

85. R. O. Fournier, U.S. Geologica1 Survey, Menlo Park, CA, personal communication (1975),

86. T. D. Palmer, personal communication (1975).

87. Dr. Howard L. Recht, personal communication (1975).

88. Lawrence Iivermore Laboratory, Geothermal Energy Development Program Status Report, Jan. 74-Jan, 75, by A. I. Austin, February 14, 1975, UCID 16-721. 